\title{
Recent Advances of Conducting Polymers and Their Composites for Electrochemical Biosensing Applications
}

\author{
John H. T. Luong ${ }^{1, *}$, Tarun Narayan ${ }^{2}\left(\mathbb{0}\right.$, Shipra Solanki ${ }^{2,3}$ and Bansi D. Malhotra ${ }^{2}(\mathbb{D}$ \\ 1 School of Chemistry and the Analytical and Biological Chemistry Research Facility (ABCRF), \\ University College Cork, College Road, T12 YN60 Cork, Ireland \\ 2 Department of Biotechnology, Delhi Technological University, Delhi 110042, India; \\ narayantarun41@gmail.com (T.N.); shiprasolanki.y29@gmail.com (S.S.); bansi.malhotra@gmail.com (B.D.M.) \\ 3 Applied Chemistry Department, Delhi Technological University, Delhi 110042, India \\ * Correspondence: luongprof@gmail.com
}

Received: 31 August 2020; Accepted: 20 September 2020; Published: 25 September 2020

\begin{abstract}
Conducting polymers (CPs) have been at the center of research owing to their metal-like electrochemical properties and polymer-like dispersion nature. CPs and their composites serve as ideal functional materials for diversified biomedical applications like drug delivery, tissue engineering, and diagnostics. There have also been numerous biosensing platforms based on polyaniline (PANI), polypyrrole (PPY), polythiophene (PTP), and their composites. Based on their unique properties and extensive use in biosensing matrices, updated information on novel CPs and their role is appealing. This review focuses on the properties and performance of biosensing matrices based on CPs reported in the last three years. The salient features of CPs like PANI, PPY, PTP, and their composites with nanoparticles, carbon materials, etc. are outlined along with respective examples. A description of mediator conjugated biosensor designs and enzymeless CPs based glucose sensing has also been included. The future research trends with required improvements to improve the analytical performance of CP-biosensing devices have also been addressed.
\end{abstract}

Keywords: biosensor; conducting polymer; enzymeless; electropolymerization; polypyrrole; polyaniline; nanomaterials; glucose

\section{Introduction}

Electroanalysis is commonly performed on a flat electrode of noble metals (gold, platinum, palladium, etc.), carbon-based materials (glassy carbon, highly ordered pyrolytic graphite, boron-doped diamond, etc.), indium tin oxide (ITO), screen printed electrode (SPE), etc. For enhanced sensitivity, the electrode surface is modified with metal nanoparticles, carbon nanotubes, carbon monoliths, quantum dots, graphene/its derivatives, and conducting polymers (CPs). A review of the use of advanced nanomaterials in biosensor construction is available elsewhere [1]. The selective signal response is based on a specific biorecognition element, which is confined to the sensing area of the electrode by physical adsorption or covalent bonding. In this context, CPs with excellent electrical conductivity, high electronic affinity, and low ionization potential play several key roles in biosensor performance. They are easily polymerized on the electrode surface by a noble salt or a dopant to augment conductivity, catalytic activity, and high surface area. High conductivity is always a desired feature to minimize the interface resistance between the electrolytes, resulting in high signal response. In a broad sense, $\mathrm{CPs}$ encompass $\pi$-conjugated polymers and polymers whose backbone has alternating single and double (or triple) covalent bonds. Since their discovery, CPs have been extensively used in the biomedical field for biosensor fabrication and tissue engineering. The non-conducting polymers can be used to give mechanical support to the sensor membranes, but CPs improve the sensitivity 
and stability of the sensing devices along with providing strength. Another property that makes CPs ideal matrices for biosensors is their excellent biocompatibility; CPs have shown extremely stable immobilization of biomolecules on their surface with complete retention of their activity. The most common methods used are cross-linking, covalent binding, physical entrapment, and adsorption [2].

Polymers with amino groups (- $\left.\mathrm{NH}_{2}\right)$ and carboxyl groups $(-\mathrm{COOH})$ are easily bioconjugated with the required biorecognition molecules such as enzymes, antibodies, and DNA. Thiolated biomolecules, mostly DNA, self-assemble on conducting polymers decorated with gold or silver nanoparticles. Conducting polymers can be incorporated with hydrogels swollen with water to form conducting porous polymer hydrogels with several desired features for biosensing platforms [3]. Conducting porous polymer hydrogels exhibit ultra-high conductivity, high mechanical properties, hierarchical structure, and swelling nature. High porosity facilitates the diffusion of the analyte and its product(s) in and out of the sensing electrode. Hydrogels swell with water, are biocompatible and serve as an excellent milieu to accommodate and prolong the activity of fragile recognition molecules.

Among four classical conducting polymers, polypyrrole (PPY) and its derivatives have been used extensively in biosensor construction. They are biocompatible and protect electrodes from fouling and rarely cause any significant disturbance of the working environment. In some cases, they form perm-selective films to exclude endogenous electrochemically active interferents. Polyaniline (PANI), another common conducting polymer, loses its conductivity at $\mathrm{pH}$ levels above 4 , so it is commonly used with another conducting polymer, nanoparticles, or carbon nanomaterials, mainly carbon nanotubes (CNT) and graphene.

Electrochemical polymerization (EP) has three different steps: (i) solubilization of oligomers in the diffusion layer after monomer oxidation, (ii) their deposition by nucleation followed by growth, and (iii) chain propagation by solid-state polymerization [4]. However, a general mechanism for each polymer cannot be easily established as the process is governed by operating parameters, except for the initial oxidation step $[4,5]$. The properties of electropolymerized films are dependent upon electrode materials, dopants, electrolyte, monomers, $\mathrm{pH}$, and electrochemical deposition methods. Comprehension of nucleation and growth kinetics allows for the tailoring of polymer properties like density, morphology, and crystallinity, according to requirement. CPs with carboxyl or amino groups serve as immobilization matrices for covalent attachment of recognition molecules [6-9]. Some polymers like polyphenanthroline facilitate the direct electron transfer (DET) from the active site of biomolecules and the electrode [10]. In some cases, a composite of two polymers, PPY and PANI, are used together to anchor the enzyme on the electrode [11].

This review paper provides an updated overview of CPs based biosensing platforms, based on publications during 2018 to 2020. Literature searches frequently encounter several claims for the choice of electrochemical biosensors and immunosensors: simplicity, high sensitivity, robustness, mass production, miniaturization, multiplexing, and portability. A critical assessment of their analytical performances will be addressed, whether CPs can provide an attractive paradigm in terms of preparations and applications. Except for the non-enzymatic detection of glucose, the use of CPs without a biorecognition molecule to form a chemosensor is excluded in this review regardless of whether the target analyte is a biomolecule. To facilitate reading, biosensing platforms based on conducting polymers, polymer composites, and direct electron transfer are discussed separately. The analytical performances of such biosensors are also tabulated in three different tables for comparison.

\section{Electrochemical Polymerization}

Conducting monomers can be polymerized by chemical or electrochemical methods. The former produces powders in bulk and is suitable for mass production while the latter results in thin films on the electrode surface with controlled thickness and characteristics. In EP, a solvent consisting of the desired monomer and an anionic doping salt is subjected to an anodic potential. The monomer is oxidized to form the radical cation, which reacts with other neighboring monomers leading to the formation of oligomeric products and eventually polymer deposition at the anode. Both the selected 
solvent and the doping salt must be stable at the oxidation potential required for EP. The choice of the solvent depends upon the target monomer, e.g., pyrrole is water-soluble, but thiophene is not. Acetonitrile and propylene carbonate are commonly used as the solvent due to their high relative permittivities and permit the use of very large potential windows. EP is commonly performed by cyclic voltammetry $(\mathrm{CV})$, potentiostatic/galvanostatic polarization. The cyclic potential sweep procedure is simple but time-consuming due to dead time in potential regions where no polymerization occurs.

Polypyrrole (PPY): Synthesis and Mechanisms. Pyrrole (PY, MW 67.09, $\mathrm{C}_{4} \mathrm{H}_{5} \mathrm{~N}, \mathrm{pK}_{\mathrm{a}}=4$ ) is water-soluble $\left(45 \mathrm{mg} / \mathrm{mL}, 0.67 \mathrm{M}\right.$ at $\left.25^{\circ} \mathrm{C}\right)$ [12] and colorless when fresh. It is also soluble in alcohol, ether, dilute acids, and in most organic chemicals [13]. Its corresponding polymer (PPY) can be easily prepared by chemical oxidative polymerization. Thus, the simple casting of PPY by evaporation of a PPY solution is simple, but the resulting film is not compact or uniform. It is also challenging to control the exact amount of PPY on the active electrode area and the film thickness. Thus, simple casting is excluded for the preparation of isolated microelectrodes and their array. In contrast, EP creates a uniform film on only electroactive surfaces with high reproducibility regardless of their dimensions. PPY is widely used in biosensor construction as the film offers several desired features and PY is commercially available. The classical CV technique offers qualitative information on the redox processes in the polymerization initially and is useful to characterize the polymer films. Potentiostatic techniques can be conducted at a constant potential or a constant current mode to provide more quantitative information to elucidate the nucleation mechanism and macroscopic growth.

Among several suggested mechanisms for the formation of PPY, the mechanism proposed by Diaz et al. [14] is frequently encountered in the literature. This mechanism deciphers several successive reactions: radical cation formation, radical coupling, and deprotonation (Scheme 1). It is challenging to probe the propagation and termination steps during EP as intermediate high oligomers are insoluble. The film thickness and morphology deserve a brief discussion here because these important parameters control the diffusion of the target analyte and its corresponding product(s) in and out of the film layer. A supporting electrolyte containing potassium iodide (KI) yields a relatively thick $(\sim 0.6 \mu \mathrm{m})$ and highly conductive film on a glassy carbon electrode (GCE), whereas KF produces a very thin film $(<0.0001 \mu \mathrm{m})$ with negligible conductivity [15]. The film thickness is $\sim 0.03-0.04 \mu \mathrm{m}$ when either $\mathrm{KClO}_{4}$, $\mathrm{KCl}, \mathrm{KBr}$, or $\mathrm{KNO}_{3}$ is included in the electrolyte, compared to $<0.01 \mu \mathrm{m}$ with $\mathrm{K}_{2} \mathrm{SO}_{4}$. EP is performed by $\mathrm{CV}$ with 40 cycles from -0.3 to $0.9 \mathrm{~V}$ vs. $\mathrm{Ag} / \mathrm{AgCl}$, at $0.1 \mathrm{~V} / \mathrm{s}$ in $0.1 \mathrm{M} \mathrm{PY}$ with $0.1 \mathrm{M}$ of the above salts. The film thickness only increases very slowly after the second cycle of $\mathrm{CV}$. The film thickness is also governed by different electrochemical methods and their associated operating parameters. As an example, the PPY film thickness obtained from electrosynthesis at a constant potential of $0.90 \mathrm{~V}$ vs. $\mathrm{Ag} / \mathrm{AgCl}$, at $20 \mathrm{~s}$ and $300 \mathrm{~s}$ is about $\sim 2 \mu \mathrm{m}$ and $>25 \mu \mathrm{m}$ in the electrolyte consisting of $0.1 \mathrm{M}$ PY and $0.1 \mathrm{M}$ potassium iodide [15]. Except for the use of $\mathrm{KF}$, other salts at a concentration of $0.1 \mathrm{M}$ provide a film with thickness ranging from above $5 \mu \mathrm{m}$ to $\sim 8 \mu \mathrm{m}$. In situ atomic force microscopy (AFM) is a great tool to probe the morphology and thickness of the film. For thicknesses below $1 \mu \mathrm{m}$, the film exhibits a globular-shaped structure and is independent of the dopant used. Thicker chloride-doped and perchlorate-doped films show cauliflower's structures [16].

PPY films prepared at lower temperatures have poorer adhesion with an uneven appearance as compared to those prepared at higher temperatures as highly conductive PPY films $(500 \mathrm{~S} / \mathrm{cm})$ can be prepared at $10^{\circ} \mathrm{C}$ [17]. However, if the recognition biomolecule is entrapped by the PPY film in a one-step reaction, the experiment must be conducted at a moderate temperature. The PPY stability in aqueous solution depends on $\mathrm{pH}$ as it undergoes protonation in strong acids ( $\mathrm{pKa}$ of 2-4) and deprotonation in a basic solution ( $\mathrm{pK}_{\mathrm{a}}$ of 9-11). The conductivity decreases from $10 \mathrm{~S} / \mathrm{cm}$ to $0.1 \mathrm{~S} / \mathrm{cm}$ when the $\mathrm{pH}$ increases from below 7 to $\mathrm{pH} 11$. In most biosensor applications, the recognition biomolecules are compatible at physiological $\mathrm{pH}$. The effect of water on the properties of PPY is another important point. Water exhibits stronger basicity than PY and captures the $\mathrm{H}^{+}$ generated during the EP to prevent the formation of the PY trimer [18]. Solvents like methanol, ethanol, and tetrahydrofuran, are more basic as compared to PY and are not capable of deprotonating the 
intermediate radical cations. Thus, their use is as effective as water to avoid the passivation of the electrode by preventing the plausible formation of the PY trimer. Additionally noteworthy, is the over oxidation of PY, which results in a non-conductive film. For repeated analyses, the PPY film must be firmly attached to the electrode surface, therefore, the deposition of a conducting polymer must be carefully performed and optimized accordingly.

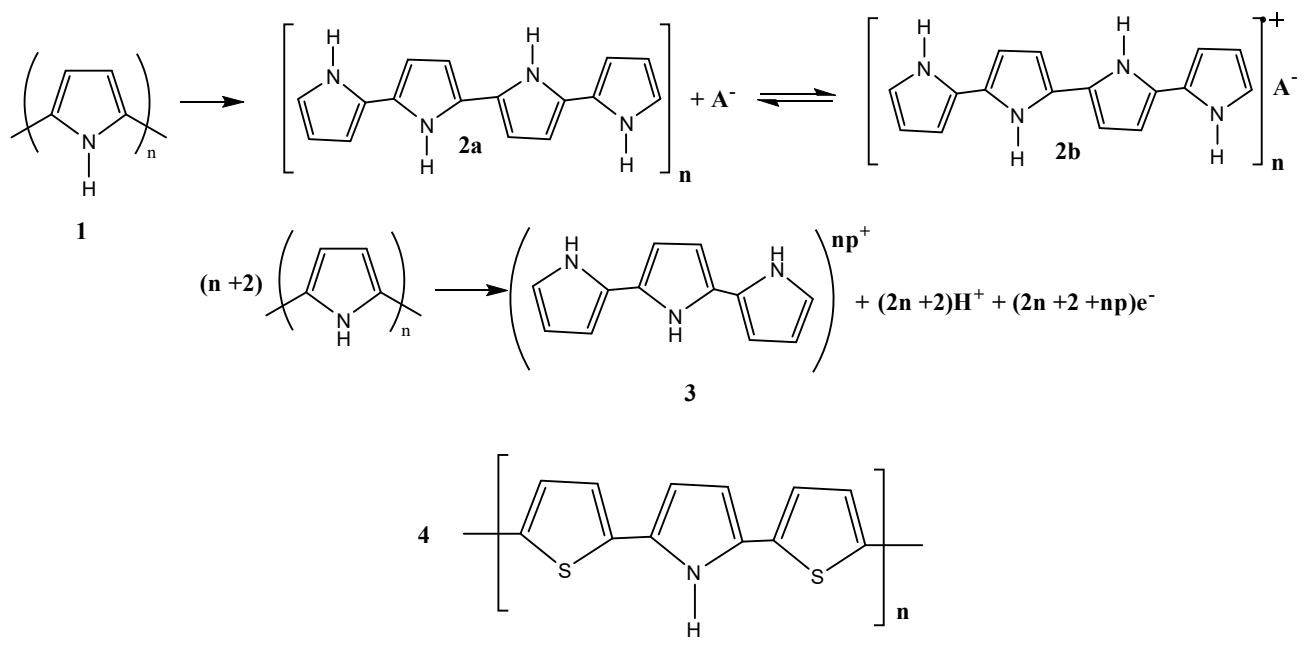

Scheme 1. (1) Simple structural representation of polypyrrole (PPY); (2-3) overall reaction of polymerization and doping, and (4) poly(2,5-di-(-2-thienyl)-pyrrole.

Among several commercial PY derivatives, 4-(3-pyrrolyl)butyric acid and 3-(1H-pyrrol-1-yl)1-propanamine are useful for bioconjugation with the $\mathrm{NH}_{2}$ or $\mathrm{COOH}$ groups of recognition biomolecules via $-\mathrm{NH}_{2}$ bonding, glutaraldehyde crosslinking or carbodiimide covalent bonding between the $-\mathrm{NH}_{2}$ and -COOH groups [19]. An electropolymerized pyrrolepropylic acid (PPA) film with a high density of $-\mathrm{COOH}$ groups is used to covalently attached protein probes, leading to significantly improved detection sensitivity compared with conventional entrapment methods [9]. Poly(N-methyl pyrrole), synthesized from $N$-methyl pyrrole, exhibits a conductivity three orders of magnitude lower than that of PPY [14]. Poly(2,5-di-(-2-thienyl)-pyrrole can be doped with para-toluene sulfonate with electrical conductivities between $10^{-8}$ and $10^{-1} \mathrm{~S} / \mathrm{cm}$ [20].

Polyaniline (PANI): Synthesis and Mechanims. Like PPY, PANI is prepared by chemical or electrochemical oxidative polymerization of aniline $\left(\mathrm{C}_{6} \mathrm{H}_{5} \mathrm{NH}_{2}, \mathrm{MW}=93.13\right.$, solubility in water $=36 \mathrm{~g} / \mathrm{L}$ at $20{ }^{\circ} \mathrm{C}$ ). Other techniques involve photochemically initiated polymerization [21,22], and enzyme-catalyzed polymerization $[23,24]$. EP of aniline is performed in an acidic electrolyte ( $\mathrm{pH} 1-3)$ as short conjugation oligomeric materials with different properties are formed at higher $\mathrm{pH}$ [25]. The first anodic oxidation is rate-determining and irreversible to produce cation radicals [26]. The formation of radicals is confirmed by introducing resorcinol, hydroquinone, benzoquinone, etc. to retard and even terminate the reaction [27]. The subsequent steps are highly dependent upon the reaction conditions if two anilinium radicals at the electrode surface form a dimer (Scheme 2). The stable radical cations react to form low molecular weight products that are soluble with aniline, whereas the unstable cation radicals react very fast with anions or solvent molecules to form undesirable side products [28]. The chain propagation step involves the simultaneous oxidation of the dimer and aniline on the anode followed by the coupling of oligomer radical cations with anilinium radical cation. Finally, anion from the dopant adds to the polymer backbone to form the conducting polymer (Scheme 2). 


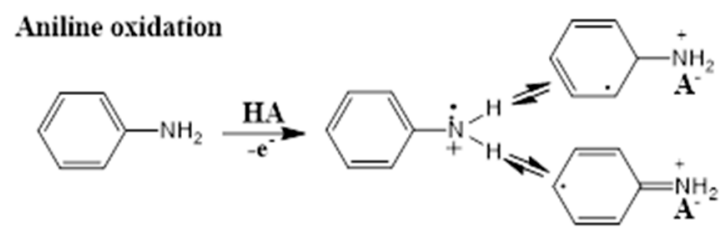

Coupling of radicals

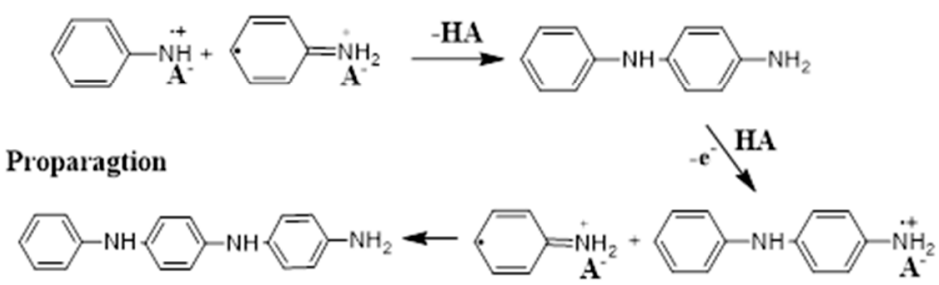

Polyaniline oxidation and doping

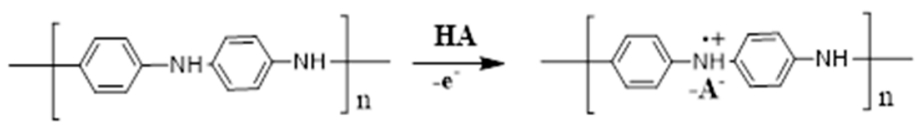

Scheme 2. Synthesis steps of polyaniline (PANI) and its resonance structures.

The application of polyaniline in biochemical systems might be limited as this polymer losses its activity at $\mathrm{pH}$ above $4[29,30]$. The deposition of aniline $(0.1-1.0 \mathrm{M})$ is commonly performed under sulfuric acid [31] or hydrochloric acid [32]. Aniline can also be electropolymerized in aqueous electrolytes, acetonitrile, and ionic liquids [11,25]. The introduction of "so-called" pH functional groups such as sulfo, carboxyl, or hydroxyl has been attempted [30]. Aniline can be co-polymerized with $o$-aminobenzoic acid, $m$-aminobenzoic acid, or $m$-aminobenzensulfonic acid to gain redox activity at high $\mathrm{pH}$ [25]. PANI can also be used with CNTs [33] and other nanomaterials for electrode modification as discussed later. PANI is the first commercial $\mathrm{CP}$, and some sulfonated aniline derivatives are also commercially available. This polymer serves well as a matrix for the immobilization of biomolecules and might function as a mediator for electron transfer in some enzymatic reactions. PANI can be synthesized in the form of varying nanostructures like nanospheres, nanowires, nanorods, and nanotubes. Besides glucose, PANI has been employed in various chemosensing and biosensing platforms, e.g., in the detection of cancer biomarkers, bacteria, infectious diseases, heavy metals, drugs, phenolics, pesticides, sulfites, acrylamides, etc. [34]. Like other conducting and non-conducting polymers, composites of PANI with other CPs, metallic nanoparticles, graphene, CNTs, etc. have increased surface area, conductivity, and stability. Such desired features play an important role in the development of analytical platforms for a variety of analytes valuable in the food industry, medicine, and environmental monitoring.

Synthesis of Polythiophene (PTP) and Its Analogs. With an electron-rich aromatic ring, thiophene is oxidized to form well-adhering polymeric films with high conductivity. The film thickness can be controlled by changing the polymerization time, and the structures of PTP and its analogs, as shown in Scheme 3. Of notice for bio-applications is a one-step enzyme entrapment by the EP process based on polythiophenes bearing oligo (ethylene glycol) spacers and porphyrin units [35]. 2,2'-bithiophene with lower oxidation potential, compared to thiophene, can be a good monomer. PTP and substituted PTP are electrochemically deposited as very adhesive thin films or as thick powdery deposits [36]. Poly(3,4-ethylene dioxythiophene)-polystyrene sulfonate (PEDOT: PSS) is a polymer mixture or macromolecular salt. PEDOT is a conjugated polymer with a positive charge, whereas PSS carries a negative charge due to the presence of deprotonated sulfonyl groups. There are four water-soluble polythiophene derivatives, which are synthesized via oxidative copolymerization by $\mathrm{FeCl}_{3}$ [37]. 


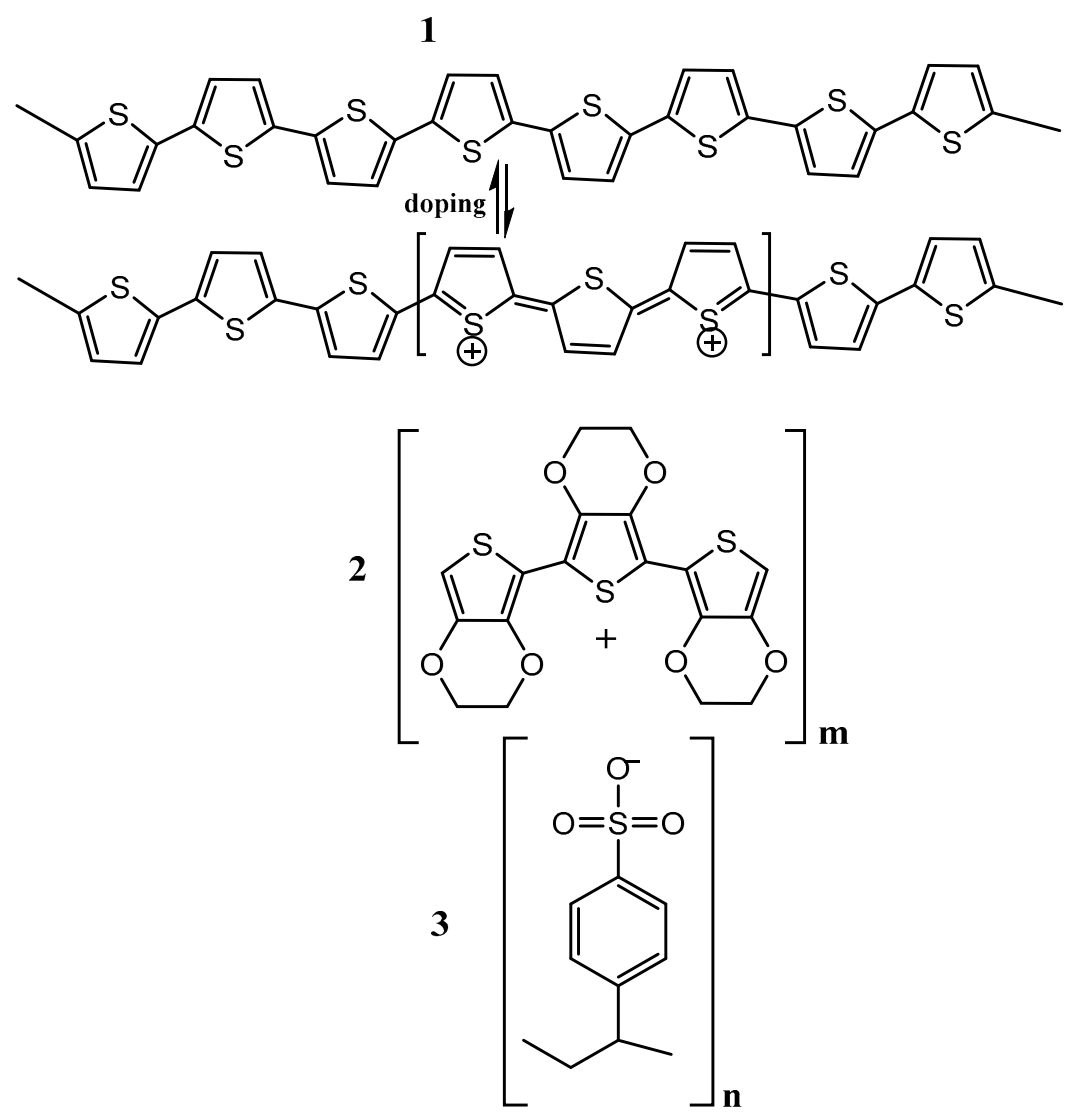

Scheme 3. (1) polythiophene (PTP), (2) poly(3,4-ethylene dioxythiophene) (PEDOT), and (3) polystyrene sulfonate (PSS).

\section{Fundamental Aspects of Electrochemistry and Biorecognition Elements}

As the oldest analytical technique, electrochemistry offers a wide range of application possibilities by probing the charge transfer between an electrode and a liquid (electrolyte) or solid phase. In electrochemical sensing, an electrode serves as the transducer element to provide the electron for signal acquisition. This approach offers several advantages such as low cost, fast analysis, and ease of miniaturization. Associated with a biorecognition element, electrochemical sensors, known as biosensors, become specific for a target analyte, as exemplified by the selective detection of glucose using glucose oxidase or glucose dehydrogenase [38].

A typical electrochemical cell consists of three-electrodes: detecting (working), reference electrode, and counter (auxiliary). The use of the counter electrode, normally a large platinum wire with a small charge-transfer resistance, overcomes the potential drop due to the current flowing through the electrochemical cell. This configuration is needed for solutions with poor electrical conductivity. The measurement can be reduced to two-electrodes with a potentiostat that connects the working electrode with a non-polarizable reference electrode, e.g., $\mathrm{Ag} / \mathrm{AgCl}(3 \mathrm{M} \mathrm{KCl})$. Electrochemical techniques can be classified into five categories: potentiometry, amperometry, voltammetry, conductometry, and impedance spectroscopy. Potentiometry is based on the measurement of voltage between a detecting electrode and a reference electrode, e.g., $\mathrm{pH}$ electrodes and other ion-selective electrodes. Amperometry relies on a redox reaction at a detecting electrode in the presence of a target analyte, which results in the variation of an electrical signal. This method has been used widely in biosensor construction for a broad range of applications. Amperometry encompasses several techniques such as voltamperometry, cyclic voltammetry, differential pulse voltammetry, square wave voltammetry, linear voltammetry, etc. 
In brief, cyclic voltammetry is first performed to establish the oxidation/reduction potentials of analytes and assess whether the redox process is reversible, pseudo-reversible, or irreversible [39]. Voltamperometry (current response at a fixed potential) is then conducted to estimate the limit of detection (LOD), linearity, detection sensitivity, stability of the biorecognition element, and reproducibility for a given biosensor. Differential pulse or square wave voltammetry is useful for analyzing multiple analytes or endogenous reactive species in the same sample [40]. Conductometric relies on the measurement of conductivity or resistivity [41]. A capacitor changes its capacitance when exposed to the desired analyte, which binds to the capacitor's surface. In impedance spectroscopy (EIS) or impedimetry, an alternative voltage $\left(\mathrm{V}_{\mathrm{ac}}\right)$ is applied with frequencies ranging from $10^{-3}$ to $10^{5} \mathrm{~Hz}$. The resulting current at the same frequency (linear system) is measured. The resulting impedance (voltage/current) is represented on a Nyquist diagram, with the imaginary part as a function of the real part. Impedance spectroscopy has been used to probe cell behavior at an electrode surface in the presence of organic compounds, drugs, nanomaterials, etc., [42,43]. Commercial electrochemical workstations are well equipped with powerful software for conducting electrochemical experiments with different techniques. This subject has been well described in several textbooks [44] and review papers concerning electrochemical sensors/biosensors [45].

Biorecognition elements can be enzymes, DNA, peptides, aptamers, whole cells, etc. and the immobilization of such biomolecules on different types of electrodes has been available elsewhere [46]. Other special cases are the immobilization of glucose oxidase on an organic transistor using a polymer brush [47] and the hybridization of DNA on conducting polymer film-modified diamond [48]. Different biosensing formats have been attempted including the fabrication of an HRP (horseradish peroxidase)-based biosensor by thermal inkjet printing [49], a glucose sensor by a nanocomposite [50], and miniaturization technologies for biosensor design [51]. The potential of continuous measurement of analytes by biosensors in biological media is also reviewed [52].

\section{Retention of Biorecognition Molecules by Conducting Polymers-Electropolymerized Polymers/Monomers}

A single-step electrochemical immobilization method is used for the production of enzyme entrapped PANI thin films for glucose and urea sensors [53]. Both enzymes and PANI are deposited simultaneously from an aqueous solution of aniline containing optimized amounts of glucose oxidase and urease for the fabrication of two different biosensors. The chronopotentiometry curves for both the biosensors differ mainly in the total time taken for deposition. Other parameters, such as the type and enzyme concentration, have a negligible effect on the curve shape. The one-step immobilization technique has helped to produce functionalized films possessing an optimal working $\mathrm{pH}$ close to that of free enzymes to conserve their conformation and microenvironment. PPY, PEDOT: PSS, and polyaminobenzoic acid (PABA) are some common polymers used in biosensor fabrication [54-57]. A biosensor for $17 \beta$-estradiol detection is fabricated based on a benzothiadiazole derivative of EDOT [58]. The use of this polymer leads to the formation of a granular defect-free surface structure with a pore diameter of $1 \mu \mathrm{m}$. This porous structure allows enzyme molecules to anchor freely in the available space with no covalent bonding. The fabricated surface has a high enzyme loading capacity and easy regeneration capability where the sensor can be regenerated just by washing with deionized water. A new semiconducting polymer poly(9-nonyl-2,7-di(selenophen-2-yl)-9H-carbazole) is used in designing biosensors for norepinephrine determination [59]. Laccase is immobilized on the surface by $\pi-\pi$ stacking involving the interaction of $\pi$-bonds in the enzyme structure with $\pi$-bonds of the aromatic backbone. The interaction stabilized the tertiary protein structure, thus improving its stability and activity. In addition to providing a surface for biomolecule immobilization, the presence of a small amount of selenium in the polymer has a positive effect on laccase catalysis.

EP has been proved as a simple and effective method to deposit conducting polymers on the conductive surface. The property of conducting polymers can be manipulated just by changing the composition of electrolytes used for polymerization. EP is performed to deposit 
zwitterionic PEDOT conducting films with antifouling properties on a conducting substrate. A mixture of thiophene-based compounds bearing phosphorylcholine (poly(2-methacryloyloxyethyl phosphorylcholine)), carboxybetaine (poly(carboxy betaine methacrylate)), and sulfobetaine (poly(sulfobetaine methacrylate) groups enhances the anti-biofouling properties [60]. The surfaces show resistance to protein and cell adhesion, which would help in improving the shelf life of the biosensors. An antifouling zwitterionic polypeptide modified with an additional linker of four residues is prepared and used for cancer biomarker BRCA1 (BReast CAncer gene) detection [61]. The composite shows strong resistance to non-specific protein adsorption and enhanced stability. Molecularly imprinted polymers (MIPs) based sensors are low cost and simple to fabricate. A typical MIP would include functional monomers, crosslinking reagents, and template molecules. As the polymer template is removed, a microcavity is formed for specifically binding target molecules with the same shape and structure as a key and lock [62]. The overuse of antibiotics is a major public health concern as they increase the chances of being antibiotic-resistant. It also harms the environment because of the pharmaceutical effluent mixing in water bodies. Amoxicillin (AMO), is one of the most popular types of aminopenicillin. It is detected by a hybrid film of (poly(methacrylamide-vinyltrimethoxysilane (VTMOS)-tetraethoxysilane (TEOS)/AMO) spin-coated on a surface plasmon resonance (SPR) gold sensor. The fabricated sensor detects the AMO down to $73 \mathrm{pM}$ and differentiates among similar molecules, both in the buffer and in water [63]. Artemisinin is also a well-known and widely used drug against malaria, a deadly disease in tropical regions of the world. Ortho-phenylenediamine (o-PD) is electropolymerized in the presence of artemisinin on the gold wire. It provides highly stable and effective binding cavities for the target molecule with a detection limit of $0.01 \mu \mathrm{M}$ [64]. However, it is still unclear how the interaction of the target molecule with functional monomers in the polymer can influence the microcavity formation. Some proteins can easily react with the polymer and change the tertiary and quaternary structure of the template, thus lowering the sensor selectivity.

For controlling the properties of CPs, different strategies have been used, and one of them is chirality. Chiral CPs with shown diverse structures enhance electronic properties and also help in redox reaction and $\mathrm{pH}$ switching [65]. They can help to understand bio-related processes due to their remarkable molecular recognition capability and distinctive self-assembling properties. The fabrication of chiral sensors is a promising field of research for electrochemists. A chiral supramolecular polymer consisting of alanine-based naphthalene diimides and Zn ions (AlaNDI-Zn) [66] exhibits multifunctional properties. Its photoconductive and chemo-resistive characteristics can be used in developing various sensors. It detects toxic hydrazine with a detection limit of $3.2 \mu \mathrm{M}$.

Hydrogels are polymers with high water retention capacity resembling biological tissues, which show great potential in biomedical applications $[67,68]$. Various target responsive hydrogels have been developed for molecular diagnostics, and wearable biosensors. A hydrogel-based localized surface plasmon resonance (LSPR) sensor is useful for detecting the biomarker in human tears. Silica gold nanoshells with poly ( $\mathrm{N}$-isopropyl acrylamide-co-methacrylic acid) (PNM) hydrogels can be used to detect lysozyme and lactoferrin. It shows potential as an affordable screening tool for chronic dry eye conditions [69]. A multiplexed biosensor based on PANI hydrogel is fabricated using an inkjet printer. The printing process consists of three steps with a multi-nozzle inkjet printer. The PANI hydrogel is printed, followed by the deposition of platinum nanoparticles, and enzymes. The multiplexed sensor can detect glucose, lactate, and triglycerides simultaneously with high selectivity in real-time [70]. A list of different polymers used for the electrochemical biosensors along with the method of biomolecule immobilization and other sensor properties are given in Table 1. 
Table 1. The use of polymers to retain the recognition molecules or modification of the electrode surface.

\begin{tabular}{|c|c|c|c|c|c|c|}
\hline Polymer (s) & Analyte & $\begin{array}{l}\text { Biomolecule } \\
\text { Immobilized }\end{array}$ & $\begin{array}{l}\text { Immobilization } \\
\text { Method }\end{array}$ & LOD & LDR & Ref. \\
\hline PANI & Glucose $(\mathrm{G})$ and urea $(\mathrm{U})$ & GOX/URE & Entrapment & - & $\begin{array}{c}0.1 \mathrm{mM}(\mathrm{G}) \\
10^{-5}-0.1 \mathrm{M}(\mathrm{U})\end{array}$ & [53] \\
\hline PPY-pTS & Hypoxanthine & XOX, URI & Entrapment & $5 \mu \mathrm{M}$ & $5 \mu \mathrm{M}-5 \mathrm{mM}$ & [54] \\
\hline PPY & Interleukin-10 & AIA & Covalent & $0.347 \mathrm{pg} / \mathrm{mL}$ & 1-10 ng/L & [55] \\
\hline NDSC & Norepinephrine & Laccase & Adsorption & $240 \mathrm{nM}$ & $0.1-200 \mu \mathrm{M}$ & [59] \\
\hline PEDOT & BRCA1 & DNA & Covalent & $0.0034 \mathrm{pM}$ & $0.01 \mathrm{pM}$ to $1 \mathrm{nM}$ & [61] \\
\hline PEDOT-PEDOT-COOH & Lactate & LDH & Covalent & $\begin{array}{c}20.26 \mu \mathrm{A} \mathrm{mM}^{-1} \mathrm{~cm}^{-1} \\
\text { (sensitivity) }\end{array}$ & $20-960 \mu \mathrm{M}$ & [71] \\
\hline PEDOT/PSS hydrogels & $\mathrm{H}_{2} \mathrm{O}_{2}$ & HRP & Nafion entrapment & $\begin{array}{c}0.94 \mu \mathrm{M} \\
10 \mu \mathrm{M}\end{array}$ & $\begin{array}{c}0.0088 \text { to } 0.15 \mathrm{mM} \\
0.05-0.25 \mathrm{mM}\end{array}$ & [72] \\
\hline PPY/PSS & Glucose & GOX & Entrapment & - & $0.1 \mathrm{nM}-1 \mathrm{mM}$ & [73] \\
\hline $\begin{array}{l}\text { DMAPM, VPBA, } \\
\text { EGDM, DA }\end{array}$ & Dopamine & Imprint & Entrapment & $96 \mathrm{nM}$ & $40 \mathrm{nM}-20 \mu \mathrm{M}$ & [74] \\
\hline $\begin{array}{l}\text { MAA, EDGM, } \\
\text { fluorescein-o-acrylate }\end{array}$ & Doxycycline & Imprint & Entrapment & $117 \mathrm{nM}$ & 0.2 to $6 \mu \mathrm{M}$ & [75] \\
\hline Toluidine blue & CA $15-3$ & Imprint & Entrapment & $0.10 \mathrm{U} / \mathrm{mL}$ & $0.10 \mathrm{U} / \mathrm{mL}$ to $100 \mathrm{U} / \mathrm{mL}$ & [76] \\
\hline PDA & TNT & Imprint & Entrapment & $15.4 \mathrm{nM}, 14.8 \mathrm{nM}$ & $0-289 \mathrm{nM}$ & {$[77]$} \\
\hline o-DB, o-PD & Chlorpyrifos & Aptamer imprint & Entrapment & $0.35 \mathrm{fM}$ & 0.001 to $0.4 \mathrm{pM}$ & [78] \\
\hline $\begin{array}{c}\text { Macroporous PANI, } \\
\text { PSS }\end{array}$ & AFP & $\mathrm{AFP} A b$ & Covalent & $3.7 \mathrm{fg} / \mathrm{mL}$ & 0.01 to $1000 \mathrm{pg} / \mathrm{mL}$ & [79] \\
\hline CuPT-PPy/NIPAAm-AM & Melanoma & CRP & Covalent & $7.85 \times 10^{-19} \mathrm{M}$ & $10^{-20}$ to $10^{-6} \mathrm{M}$ & [80] \\
\hline $\begin{array}{l}\text { NiPAAm, AAm, } \\
\text { MBAAm }\end{array}$ & BSA & Imprint & Entrapment & $0.012 \mu \mathrm{M}$ & $0.02 \mu \mathrm{M}$ to $10 \mu \mathrm{M}$ & [81] \\
\hline $\begin{array}{c}\text { FcMMA, 4-VP, and } \\
\text { EDMA }\end{array}$ & Bisphenol A & Imprint & Entrapment & $13 \mathrm{ng} / \mathrm{L}$ & $0-410 \mathrm{ng} / \mathrm{L}$ & [82] \\
\hline PEDOT & $\mathrm{NADH}$ & & Physical adsorption & $5.3 \mu \mathrm{M}$ & $20-240 \mu \mathrm{M}$ & [83] \\
\hline PLL & DNAhybridization & DNA & Covalent & $2.25 \times 10^{-14} \mathrm{M}$ & $1.0 \times 10^{-13}$ to $1.0 \times 10^{-6} \mathrm{M}$ & [84] \\
\hline PPY & CEA & Imprint & Entrapment & $0.13 \mathrm{pg} / \mathrm{mL}$ & $0.125-12.25 \mathrm{pg} / \mathrm{mL}$ & [85] \\
\hline PCPy & Glucose & GOX & Entrapment & $0.039 \mathrm{mM}$ & $0.1-15.0 \mathrm{mM}$ & [86] \\
\hline PSBEDOT & Glucose & GOX & Entrapment & - & $1 \mathrm{mM}$ to $20 \mathrm{mM}$ & [87] \\
\hline
\end{tabular}


Table 1. Cont

\begin{tabular}{|c|c|c|c|c|c|c|}
\hline Polymer (s) & Analyte & $\begin{array}{l}\text { Biomolecule } \\
\text { Immobilized }\end{array}$ & $\begin{array}{l}\text { Immobilization } \\
\text { Method }\end{array}$ & LOD & LDR & Ref. \\
\hline BTP & Glucose & GOX & Entrapment & $0.034 \mathrm{mM}$ & $0.034-1.0 \mathrm{mM}$ & [88] \\
\hline PPY & Glucose & GOX of $A$. niger & Coating the cell & $0.005 \mathrm{mM}$ & $0.01-0.05 \mathrm{mM}$ & [89] \\
\hline PPY & Catechol & $\begin{array}{l}\text { POX (Trametes } \\
\text { pubescens) }\end{array}$ & Encapsulation & $1.8 \mu \mathrm{M}$ & $1-60 / 70 \mu \mathrm{M}$ & [90] \\
\hline $\begin{array}{l}\text { p-toluene-sulfonic } \\
\text { acid doped PPY }\end{array}$ & Glucose & GOX & Physical adsorption & $\begin{array}{c}0.25 \mathrm{mM} \text { is lowest } \\
\text { tested }\end{array}$ & $0.25-1.5 \mathrm{mM}$ & [91] \\
\hline BOTT & Catechol & Laccase & Entrapment & $0.38 \mu \mathrm{M}$ & $0.5-25 \mu \mathrm{M}$ & [92] \\
\hline PEDOT(BSA) & Glucose & GOX & Physical adsorption & $0.416 \mathrm{mM}$ is tested & 0.416 to $50 \mathrm{mM}(\mathrm{LSV})$ & [93] \\
\hline DPDAA & Glucose & G. oxydans and GOX & $\begin{array}{l}\text { Glutaraldehyde } \\
\text { cross-linking Cells: }\end{array}$ & $\begin{array}{c}0.022 \mathrm{mM} \text { (GOX) } \\
0.081 \mathrm{mM} \text { (whole cell) }\end{array}$ & $\begin{array}{c}0.045-50.0 \mathrm{mM} \text { (GOX) and } 0.19-50.0 \mathrm{mM} \\
\text { (whole cell) }\end{array}$ & [94] \\
\hline PANI & E. coli & Anti-E. coli antibody & Covalent & $10 \mathrm{CFU} / \mathrm{mL}$ & $10^{1}-10^{6} \mathrm{CFU} / \mathrm{mL}$ & [95] \\
\hline $\begin{array}{l}\text { Macroporous } \\
\text { PPY-pyrrole }\end{array}$ & Urea & Urease & Entrapment & $2.57 \mathrm{mM}$ & $1.67-8.32 \mathrm{mM}$ & [96] \\
\hline
\end{tabular}

Polymers: AAm = acrylamide, BOTT = thienothiophene-benzoxadiazole-alt-benzodithiophene, BTP = 5-amino-N1,N3-bis (2,5-di(thiophen-2-yl)-1H-pyrrol-1-yl) isophthalamide,

$\mathrm{DA}=3$-hydroxytyramine hydrochloride, DMAPM $=N$-[3-(dimethylamino)propyl]methacrylamide, DPDAA = 10-(4H-dithiyeno [3,2-b:2', $3^{\prime}$-d $]$ pyroll-4-il)decan-1-amine,

EGDM = ethylene glycol dimethacrylate, FcMMA= Ferrocenyl methylmethacrylate, MAA = methacrylic acid, MBAAm = methylene- $N, N$-bis(acrylamide),

NDSC = 9-nonyl-2,7-di(selenophen-2-yl)-9H-carbazole, NiPAAm $=N$-isopropylacrylamide, $\mathrm{o}$-DB $=\mathrm{o}$-Dihydroxybenzene, $\mathrm{PANI}=$ polyaniline, PBETB poly(4,7-bis(5-(3,4-ethylenedioxythiophene)thiophen-2-yl)benzothiadiazole), PEDOT = poly(3,4-ethylenedioxythio phene), pTS = para toluene sulphonate, PLL = Poly-L-lysine, $\mathrm{PPy}=$ poly pyrrole, PSBEDOT = poly(sulfobetaine-3,4-ethylenedioxythiophene), PSS = poly styrene sulphonate, VPBA = 4-vinylphenylboronic acid, 4-VP = 4-vinylpyridine. Biorecognition biomolecules: AFP = alpha-fetoprotein, AIA = Anti-Interleukein antibody, BSA = bovine serum albumin, CA 15-3 = Carbohydrate Antigen 15-3, CEA = Carcinogenic embryonic antigen, $\mathrm{CRP}=\mathrm{C}$-reactive protein, $\mathrm{GOX}=$ glucose oxidase, $\mathrm{HRP}=$ horseradish dehydrogenase, $\mathrm{LDH}=$ lactate dehydrogenase, $\mathrm{POX}=$ polyphenol oxidase, $\mathrm{TnT}=\mathrm{Cardiac}$ Troponin $\mathrm{T}$, $\mathrm{URA}=$ urease, $\mathrm{URI}=$ uricase, $\mathrm{XOX}=$ xanthine oxidase 


\section{Conducting Polymer Composites}

The properties of polymers can be improved by the addition of fillers and the formation of composites. The most used materials for polymer composite formation are CNTs, carbon nanofibers, graphene and its derivatives, other carbon materials, metal nanoparticles, and metal oxide nanoparticles. CNTs improve the electrical and thermo-mechanical properties of CPs thin films. In general, composites of polymers with both multiwalled CNTs (MWCNTs) and single-walled CNTs (SWCNTs) have been used for several analytes with enhanced sensitivity and stability due to increased and faster biomolecule to electrode charge transfer as well as improved biomolecule activity. Graphene is another carbon-based nanomaterial that has been used widely in electronic devices. A field effect transistor (FET) based on a composite of graphene and poly(3-aminobenzylamine-co-aniline) exhibits extremely sensitive detection of acetylcholine. The amine-functionalized polymer provides a suitable environment for enzyme immobilization and improves the $\mathrm{pH}$ sensitivity of the graphene-based FET owing to a wide $\mathrm{pK}_{\mathrm{a}}$ distribution of polymer components [97]. An electrochemical comparison between GO/PEDOT and $\mathrm{rGO} / \mathrm{PEDOT}$ composite reveals that GO enhances the capacitive behavior of the polymer film more than rGO [98]. Currently, porous carbon with a high conductivity and surface area has emerged as a new cost-effective material for screen printed electrodes used in biosensing devices. Its electrocatalytic properties can be further enhanced by doping carbon with heteroatoms like B (boron), N (nitrogen) or $\mathrm{S}$ (sulfur). The detection of neurotransmitters and lactic acid is feasible using the composites of $\mathrm{N}$ and $S$ doped carbon with polymers like poly 3-((2,2':5',2'-terthiophen)-3'-yl)-5-aminobenzoic acid (pTTABA)) and 2, 2':5',5'"-terthiophene-3'-p-benzoic acid (TBA) [99,100]. The core-shell nanocomposite of Pt-Pd with N-doped carbon shell acetylcholine biosensor is fabricated for organophosphate pesticide detection in "real-world" samples. The composites of porous carbon with polymers show better electrocatalytic properties and conductivity. Its detection limit for malathion, chlorpyrifos, and parathion is $7.9 \times 10^{-15} \mathrm{M}, 7.1 \times 10^{-14} \mathrm{M}$, and $8.6 \times 10^{-15} \mathrm{M}$, respectively [101]. Carbon dots (CDs) are the fluorescent nanosized carbon particles which have attracted much attention since their discovery. In comparison to other carbon materials, CDs are easy to synthesize, small, hydrophilic, and can be modified with various functional groups. CDs with fluorescent and photophysical properties are often mixed with polymers to enhance the electron transport and stimulate fast redox reactions. CDs are mixed with chitosan for the determination of glucose as the composite enhances the electron transfer and provides a biocompatible sensor surface. The CDs increased the conductivity and 3-aminobenzeneboronic acid as the monomer for the fabrication of MIP. The fabricated sensor exhibits a limit of detection (LOD) of $0.09 \mu \mathrm{M}$ with excellent stability, and reproducibility [102]. Caffeic acid (3,4-dihydroxycinnamic) is a widely used drug for anti-inflammatory, leucopenia, and thrombocytopenia, and hemostasis. A CDs@MIPs based sensor detects this acid in human plasma with an LOD of $0.11 \mu \mathrm{M}$ and a linear range of 0.5-200 $\mu \mathrm{M}$ [102].

Graphitic carbon nitride $(\mathrm{gCN})$ is a synthetic polymer with an increase in interest in applications ranging from photoelectrochemistry, (photo)catalysis, and, biosensors [103]. Its reactive interface with an aromatic $\pi$-conjugated framework provides opportunities to control its structure and properties for a specific application. The gCN is incorporated with MIP to fabricate a self-powered biosensor based on photo-fuel cell, resulting in good detection selectivity for bisphenol A. The sensor is powered through the catalytic activity of $\mathrm{Ni}(\mathrm{OH})_{2}$ toward the oxidation of glucose [104]. An electroactive nanocomposite of Ru@Au core-shell nanoparticles, gCN nanotubes, and functionalized graphene quantum dots is used to detect phenylethanolamine A [103]. The fabricated sensor with an LOD of $2.0 \times 10^{-13} \mathrm{M}$ is tested on the urine sample with good selectivity for phenylethanolamine A. Gold nanoparticles (AuNPs) are the most used metal nanoparticles in biosensors. An interesting antifouling biosensing platform is constructed using AuNPs and PEDOT, where AuNPs acted as signal enhancers, whereas the polymer assisted in the antifouling behavior of the sensor surface [105]. The device is tested in biological media for CA15-3 detection, and it shows an elongated antifouling performance with only a negligible activity change during 30 days. Natural clay has been under research as a transducer surface modification agent due to its stability, porosity, high cation exchange capacity, low price, 
and widespread availability $[106,107]$. A glucose biosensor based on a platinum disk modified with PANI, chitosan, montmorillonite clay particles, and platinum nanoparticles shows extended stability up to two months with excellent stability and selectivity [108]. Thus, clay particles can be used to increase the stability of the polymer surface-modified electrode. Of interest is the fabrication of poly (3,4-ethylenedioxythiophene)-iridium oxide nanocomposite based tyrosinase biosensor for the dual detection of catechol $(\mathrm{LOD}=0.017 \mu \mathrm{M})$ and azinphos methyl $(\mathrm{LOD}=2.964 \mu \mathrm{M})$ [109]. Anziphos methyl is a broad spectrum organophosphate insecticide and the measurement is based on the inhibition of the activity of tyrosinase. Ferrocene-substituted 2,5-di(thienyl)pyrrole (SNS-Fc) can be electrochemically polymerized with 3,4-ethylenedioxythiophene (EDOT) to serve as an immobilization matrix of GOX by cross-linking in the presence of MWCNTs [110]. 
Table 2. Polymer nanocomposites containing carbon nanotubes (CNTs), graphene, and nanoparticles in biosensors.

\begin{tabular}{|c|c|c|c|c|}
\hline Nanocomposite & Target Analyte & LOD & LDR & Ref. \\
\hline PEDOT: PSS/ $\mathrm{Fe}_{2} \mathrm{O}_{3}$ & Carcinoembryonic antigen & - & $4-25 \mathrm{ng} / \mathrm{mL}$ & [56] \\
\hline PABA and Graphene & Acetylcholine & 5 to $1000 \mu \mathrm{M}$ & $2.3 \mu \mathrm{M}$ & [97] \\
\hline PTAB and $\mathrm{N}, \mathrm{S}$ doped porous carbon & Lactic acid & $0.5 \mu \mathrm{M}$ and $4.0 \mathrm{mM}$ & $112 \mathrm{nM}$ & [99] \\
\hline PEDOT and AuNPs & CA15-3 & $0.001-1000 \mathrm{U} / \mathrm{mL}$ & $0.32 \mathrm{mU} / \mathrm{mL}$ & [105] \\
\hline $\mathrm{MnO}_{2} / \mathrm{PAA}-\mathrm{GG}$ & $\mathrm{H}_{2} \mathrm{O}_{2}$ & $10 \mu \mathrm{M}$ & $0.05 \mathrm{mM}-50 \mathrm{mM}$ & [111] \\
\hline PEG/graphene/aptamer & $\mathrm{IgG}$ & $47 \mathrm{pM}$ & $50 \mathrm{pM}-250 \mathrm{nM}$ & [112] \\
\hline PQQ-GDH/PTh/MWCNT & Glucose & $1 \mu \mathrm{M}$ & $1 \mu \mathrm{M}$ to $2 \mathrm{mM}$ & [113] \\
\hline PANI/MWCNTs/Starch & Cholesterol & $0.01 \mathrm{mM}$ & 0.032 to $5 \mathrm{mM}$ & [114] \\
\hline GOX-PtNPs-PEDOT-MS & Glucose & $1.55 \mu \mathrm{M}$ & $0.1-10 \mathrm{mM}$ & [115] \\
\hline $\mathrm{CeO}_{2}$-NRs/Ppy-NPs ssDNA probe (covalent) & DNA from Salmonella & $0.29 \mu \mathrm{M}$ & $1.0 \mathrm{nM}-1 \mu \mathrm{M}$ & [116] \\
\hline PIn-5-COOH/MWCNTs-COOH & $\alpha$-fetoprotein & $0.33 \mathrm{pg} / \mathrm{mL}$ & $0.001-100 \mathrm{ng} / \mathrm{mL}$ & [117] \\
\hline poly(pyrrole-3-carboxylic acid)/GO with GOx & $\begin{array}{c}\text { Glucose } \\
\text { (ITO coated glass) } \\
\end{array}$ & $0.05 \mathrm{mM}$ & $1-20 \mathrm{mM}$ & [118] \\
\hline PAnNFs-P(An-co-PoPD)] & Glucose (GOX) & Minimal glucose conc. tested is $5 \mu \mathrm{M}$ & Saturation at $0.45-0.6 \mathrm{mM}$ & [119] \\
\hline PDA-MWCNTs-PB & $\begin{array}{l}\text { Cholesterol (Ch) } \\
\text { (Ch oxidase/SPE) }\end{array}$ & $1.5 \mu \mathrm{M}$ & Linear up to $0.4 \mathrm{mM}$ & [120] \\
\hline PEG-PPY nanowires & DNA probe for miRNA & $0.033 \mathrm{pM}$ & $0.10 \mathrm{pM}-1.0 \mathrm{nM}$ & [121] \\
\hline rGO-PEDOT:PSS & GOX fpr glucose & $86.8 \mu \mathrm{M}$ & $\begin{array}{l}\text { Detection range: } 100 \mu \mathrm{M} \text { to } 600 \\
\mu \mathrm{M}\end{array}$ & [122] \\
\hline PPY-Ag/ZnO on pencil graphite electrode & $\begin{array}{l}\text { Xanthine }(\mathrm{X}) \\
\text { (X oxidase) }\end{array}$ & $0.07 \mu \mathrm{M}$ & $0.06-0.6 \mu \mathrm{M}$ & [123] \\
\hline P(SNS-An-co-EDOT) & Glucose (GOX) & $1.9 \mu \mathrm{M}$ & $0.01-5.0 \mathrm{mM}$ & [124] \\
\hline PPY-CNTs/( $\left.\mathrm{SrCuO}_{2}\right)$ & $\begin{array}{l}\text { 2,4-dichlorophenol (laccase-graphite } \\
\text { electrode) }\end{array}$ & 0.18 & $1-50 \mu \mathrm{M}$ & [125] \\
\hline PPY bearing the redox dendrimer PAMAM G2 & $\begin{array}{l}\text { autocrine motility factor (cytokine)-cancer } \\
\text { biomarker }\end{array}$ & $43 \mathrm{fM}$ & $1 \mathrm{pM}-1 \mu \mathrm{M}$ & [126] \\
\hline PANI/PPY/MWCNTs-COOH & $\begin{array}{c}\mathrm{H}_{2} \mathrm{O}_{2} \\
\text { (Cytochrome C) }\end{array}$ & $0.1 \mu \mathrm{M}$ & $1-370 \mu \mathrm{M}$ & [127] \\
\hline ePDA & $\begin{array}{c}\mathrm{AA} \\
\text { (Laccase) }\end{array}$ & $\begin{array}{c}\text { The lowest AA tested is } 7 \mu \mathrm{M}(\mathrm{CV} \\
\text { mode) }\end{array}$ & $\begin{array}{l}\text { Sensitivity }=342 \mathrm{~mA} / \mathrm{Mcm}^{2} \\
\text { with a linearity of } 1-25 \mu \mathrm{M}\end{array}$ & [128] \\
\hline
\end{tabular}


Table 2. Cont.

\begin{tabular}{|c|c|c|c|c|}
\hline Nanocomposite & Target Analyte & LOD & LDR & Ref. \\
\hline $\mathrm{Pt} / \mathrm{rGO} / \mathrm{P} 3 \mathrm{ABA}$ & $\begin{array}{c}\text {-Glucose (GOX) } \\
\text {-Cholesterol (ChOx) }\end{array}$ & $\begin{array}{l}44.3 \mu \mathrm{M} \\
40.5 \mu \mathrm{M}\end{array}$ & $\begin{array}{l}0.25-6.00 \mathrm{mM} \\
0.25-4.00 \mathrm{mM}\end{array}$ & [129] \\
\hline PtNPs, MWCNTs-COOH-PEDOT:PSS & $\begin{array}{c}\text { Glutamate } \\
\text { Glutamate Oxidase }\end{array}$ & $\begin{array}{c}0.5 \mu \mathrm{M} \text { at } 0.5 \mathrm{~V} \\
0.5 \mu \mathrm{M} \text { at } \\
-0.2 \mathrm{~V}\end{array}$ & $\begin{array}{c}1 \mu \mathrm{M} \text { and } 800 \mu \mathrm{M} \\
10 \mu \mathrm{M} \text { and } 600 \mu \mathrm{M}\end{array}$ & [130] \\
\hline Cu-BTC-PANI on ITO & $\begin{array}{c}\text { E.coli } \\
\text { (anti-E.coli antibody) }\end{array}$ & $\begin{array}{c}\text { E. coli } \\
(2 \mathrm{cfu} / \mathrm{mL})\end{array}$ & Linearity: $2-2 \times 10^{8} \mathrm{cfu} / \mathrm{mL}$ & [131] \\
\hline PBA-pTBA & $\begin{array}{l}\text { Glucose } \\
\text { (GOX) }\end{array}$ & $0.29 \mu \mathrm{M}$ & $1 \mu \mathrm{M}-30 \mathrm{mM}$ & [132] \\
\hline PDA & $\begin{array}{c}\text { ABTS } \\
\text { (Laccase) }\end{array}$ & $0.29 \mu \mathrm{M}$ & $1-150 \mu \mathrm{M}$ & [133] \\
\hline $\mathrm{PANI} / \mathrm{rGO} / \mathrm{Au} \mathrm{NPs}$ & $\begin{array}{l}\text { Glucose } \\
\text { GOX }\end{array}$ & $64 \mu \mathrm{M}$ & $1-10 \mu \mathrm{M}$ & [134] \\
\hline $\begin{array}{c}\text { PAB/DNA-functionalized CNT/Nitrogen } \\
\text { doped graphene }\end{array}$ & Dopamine & $14 \mathrm{nM}$ & $0.02-1 \mu \mathrm{M}$ & [135] \\
\hline PANI/Au NPs & $\begin{array}{c}\text { Prostate-specific antigen } \\
\text { Peptides }\end{array}$ & $0.085 \mathrm{pg} / \mathrm{mL}$ & $0.1 \mathrm{pg} / \mathrm{mL}$ to $100 \mathrm{ng} / \mathrm{mL}$ & [136] \\
\hline PAA/VS-PANI/GPL-FePc-conducting hydrogel & $\begin{array}{l}\text { Glucose } \\
\text { GOX }\end{array}$ & $6.4 \mu \mathrm{M}$ & $1-20 \mathrm{mM}$ & [137] \\
\hline MPNFs of $\mathrm{SnO}_{2} / \mathrm{PANI}$ & $\begin{array}{c}\text { Glucose } \\
\text { GOx/HRP }\end{array}$ & $1.8 \mu \mathrm{M}$ & $5-100 \mu \mathrm{M}$ & [138] \\
\hline PANI/Polyacrylamide & $\mathrm{H}_{2} \mathrm{O}_{2}$ & $2.9 \mathrm{nM}$ & $0.01-50 \mu \mathrm{M}$ & [139] \\
\hline PPY & M. tuberculosis & $0.36 \mathrm{aM}$ & $0.1 \mathrm{aM}$ to $100 \mathrm{fM}$ & {$[140]$} \\
\hline Carbon black/PVDF/SPGMA & IL-8 & $3.3 \mathrm{fg} / \mathrm{mL}$ & $0.01-3 \mathrm{pg} / \mathrm{mL}$ & [141] \\
\hline AChE/HCS@PANI & malathion & $1.0 \mathrm{ng} / \mathrm{mL}$ to $10 \mu \mathrm{g} / \mathrm{mL}$ & $0.16 \mathrm{ng} / \mathrm{mL}$ & {$[142]$} \\
\hline GO/AAM/MAA/MMA/NVP & Zika virus & $10^{-3}$ to $10^{2} \mathrm{PFU} / \mathrm{mL}$ & $2 \times 10^{-2} \mathrm{PFU} / \mathrm{mL}$ & {$[143]$} \\
\hline
\end{tabular}

AA = 2,2'-azino-bis(3-ethylbenzothiazoline-6-sulfonic acid, ABTS = 2,2'-azino-bis-(3-ethylbenzothiazoline-6-sulphonic acid), AChE = acetylcholine esteras, BTC $=1,3,5$-benzenetricarboxylic acid, $\mathrm{CMA}=4$-aminophenylacetic acid, $\mathrm{CS}=$ chitosan, $\mathrm{PABA}=$ poly(3-aminobenzylamine-co-aniline), ePDA = a co-polymer enriched by chains of dopamine in the open form in detriment of indole moieties, GPL-FePc $=$ iron phthalocyanine functionalised graphene nanoplatelets, HCS $=$ hollow carbon spheres, HRP $=$ horse radish peroxidase, $\mathrm{MMT}=$ montmorillonite, $\mathrm{MPNFs}=$ Polymerized multiporous nanofiber, $\mathrm{P}($ An-co-PoPD $)]=$ poly $($ aniline-co- $N$-phenyl-o-phenylenediamine $)$ nanoflakes, $\mathrm{P}(\mathrm{SNS}-\mathrm{An}-\mathrm{co}-\mathrm{EDOT})=$ poly (benzenamine-2,5-di(thienyl)pyrrole-co-3,4-ethylenedioxythiophene, $\mathrm{P} 3 \mathrm{ABA}=$ poly $(3$-aminobenzoic acid, $\mathrm{PAA}=$ polyacrylic acid, $\mathrm{PAB}=$ poly anilineboronic acid, PAMAM G2 = N-(5-phosphate-D-arabinoyl)-2-aminoethanamine, PAnNFs= Polyaniline nanofibers, PB = Prussian Blue, PBA = poly- $3^{\prime}($ benzoic acid $)$, PDA $=$ polydopamine,

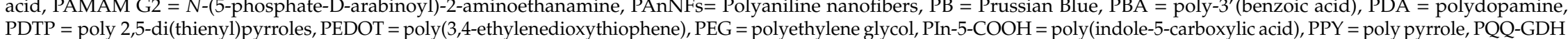
$\mathrm{PDTP}=$ poly 2,5-di(thienyl)pyrroles, $\mathrm{PEDOT}=$ poly $(3,4$-ethylenedioxythiophene), $\mathrm{PEG}=$ polyethylene glycol, $\mathrm{PIn}-5-\mathrm{COOH}=$ poly $($ indole-5-carboxylic acid $), \mathrm{PPY}=$ poly pyrrole, $\mathrm{PQQ}-\mathrm{GDH}$
$=$ pyrroloquinoline quinone dependent glucose dehydrogenase, $\mathrm{PTAB}=$ polymer $\left(\right.$ poly $3-\left(\left(\left(2,2^{\prime}: 5^{\prime}, 2^{\prime \prime}\right.\right.\right.$-terthiophen)-3'-yl)-5-aminobenzoic acid, $\mathrm{pTBA}=$ poly $\left(2,2^{\prime}: 5^{\prime}, 2^{\prime}-\right.$-terthiophene), PTh = polythiophene, PVDF= polyvinylidene fluoride, SPGMA = star poly (glycidyl methacrylate), TBA = 5"-terthiophene-3'-p-benzoic acid, VS-PANI = inyl substituted polyaniline. 
As illustrated in Table 2, conducting polymer-based composites are formed by blending or mixing $\mathrm{CPs}$ with other materials to achieve multifunctionality [144]. Resulting composites benefit from the synergistic effect of different components to exhibit multi-functionalized properties with enhanced mechanical performance and processability. The interfacial adhesion between the conducting polymer and other components affects the morphologies and electrochemical properties and morphologies of composite films, which can be attributed to novel composite properties. The presence of the amino group of aniline is needed for bioconjugation with the amino group or the carboxyl group of the biorecognition element by glutaraldehyde crosslinking or carbodiimide activation, respectively. Noble metal nanoclusters, e.g., platinum nanoclusters, can be integrated during oxidative polymerization of pyrrole to form a composite with enhanced electrochemical properties, mechanical performance, and processability [145]. The conducting polymer-based composite exhibits electrocatalysis for glucose oxidation with a linear range of 1-30 mM. However, the signal response is not provoked by common electroactive interferents such as ascorbic acid, uric acid, and 4-acetamidophenol in blood glucose analysis.

\section{Polymers Conjugated Mediators for Direct Electron Transfer (DET)}

As third generation biosensors are mainly based on DET from the enzyme-electrode surface, the polymer matrix can serve as an efficient surface for mediator attachment, thus preventing the leaching of mediator molecules and improving the electron transfer as well. Ferrocene and its derivatives are very popular redox mediators used in biosensor construction. They are very stable in both oxidized and reduced form, have excellent redox reversibility, and their redox capacity is not affected by the $\mathrm{pH}$ of the solution $[110,140]$. A highly sensitive reagentless glucose detection electrode is designed with copolymerization of ferrocene and functionalized PPY. The sensor has a detection limit of $0.43 \mu \mathrm{M}$ with a sensitivity of $23.12 \mu \mathrm{A} \mathrm{mM}^{-1} \mathrm{~cm}^{-2}$ and can detect trace analytes [110]. The functionalization with the mediator shifts the working potential from $0.6 \mathrm{~V}$ to $0.4 \mathrm{~V}$ and prevents mediator leaching, thus increasing stability and limiting the interference in real samples. A biosensor surface is modified with ferrocene and PPY for bacterial detection with a LOD of $100 \mathrm{fM}$ [140]. A sensitive microfluidic set-up coupled with a modified SPE is designed for neurotransmitter detection and able to detect the target analyte as low as $34 \mathrm{pM}$ [100]. Titanium yellow, an aromatic anionic compound, can be used to enhance PPY electroactive properties. The polymeric film with sulfonate functional groups provides enhanced conductivity and stability compared to chlorine [146].

Evans blue acting as a mediator is attached to the polymer surface by covalent linkage. It acts as an electron mediator and aids in selectivity enhancement by attracting cationic species and repelling anionic counterparts due to the presence of negatively charged sulfonate groups. The device provides a rapid, low cost and effective method for neurotransmitter detection and avoids the use of specific labels. Viologen is a well-known redox molecule containing a 4,4'-dipyridinium group. It undergoes two-electron transfer processes and exhibits three redox states, namely $\mathrm{V}^{2+}, \mathrm{V}^{+}$, and $\mathrm{V}^{0}$, making it suitable for electrochemical applications. This property of viologen is used to modify carbazole monomer by electropolymerization, which exhibits enhanced thermal stability and a large electrochemical window [131,147]. The polymer-based electrode enhances the oxidative current in the detection of uric acid and ascorbic acid. However, the mediator modification does not always increase the sensor performance. Nickel hexacyanoferrate (NiHCF) is used as a mediator for layer by layer EP of PPY-PSSA and PPY-GOX or lactate oxidase. The sensor without a mediator has higher sensitivity of $0.94 \mathrm{nA} / \mathrm{mM}$ for glucose than the mediator modified sensor $(0.32 \mathrm{nA} / \mathrm{mM})$ [148]. A list of various mediator conjugated polymer platforms used in 2020 for biosensing is given in Table 3 . 
Table 3. Biosensors consisting of mediator conjugated polymers for direct electron transfer.

\begin{tabular}{|c|c|c|c|c|}
\hline Mediator-Polymer & $\begin{array}{l}\text { Target Analyte/ } \\
\text { Sensor Platform }\end{array}$ & LOD & LDR & Ref. \\
\hline $\begin{array}{l}\text { Evans blue-poly-TBA/S,N } \\
\text { doped carbon }\end{array}$ & $\begin{array}{l}\text { Neurotransmitters } \\
\text { (Amp) }\end{array}$ & $\begin{array}{l}0.034( \pm 0.005) \mathrm{nM} \\
0.044( \pm 0.004) \mathrm{nM}\end{array}$ & $0.05-130 \mathrm{nM}$ & [100] \\
\hline Ferrocene-PPY/MWCNT & Glucose (Amp) & $2.2-0.43 \mu \mathrm{M}$ & $0.43 \mu \mathrm{M}$ & [110] \\
\hline Ferrocene-PPY & $\begin{array}{l}\text { M. tuberculosis } \\
\text { (SWV) }\end{array}$ & $1 \mathrm{aM}$ to $100 \mathrm{fM}$ & $0.36 \mathrm{aM}$ & [140] \\
\hline $\begin{array}{c}\text { Polymethylene } \\
\text { blue-PANI/MWCNT }\end{array}$ & $\begin{array}{l}\text { Cardiac troponin } \mathrm{T} \\
\text { (DPV) }\end{array}$ & $0.10-8.0 \mathrm{pg} / \mathrm{mL}$ & $0.040 \mathrm{pg} / \mathrm{mL}$ & [149] \\
\hline Ferrocene-PAA hydrogel & miR-21 (DPV) & $10 \mathrm{nM}$ to $50 \mu \mathrm{M}$ & $5 \mathrm{nM}$ & [150] \\
\hline BG-PAA & Glucose (Amp) & $\begin{array}{l}0.25-5.0 \mathrm{mM} \\
0.1-1.75 \mathrm{mM}\end{array}$ & $0.055 \mathrm{mM}$ & [151] \\
\hline FcAPS/GCE & $\mathrm{H}_{2} \mathrm{O}_{2}$ (Amp/Fluors) & $10 \mu \mathrm{M}$ to $10 \mathrm{mM}$ & $2.07 \mu \mathrm{M}$ & [152] \\
\hline FPS/MWCNT-PDDA & $\begin{array}{l}\text { Acetaminophen } \\
\text { (DPV) }\end{array}$ & 3 to $1100 \mu \mathrm{M}$ & $0.6 \mu \mathrm{M}$ & [153] \\
\hline PEDOT/AuNPs-MWCNT-COOH & $\begin{array}{c}\text { Catechol } \\
\text { Laccase (DPV) }\end{array}$ & 0.11 and $12.26 \mu \mathrm{M}$ & $\begin{array}{c}\text { Two linear ranges: } \\
0.1-0.5 \text { and } \\
11.99-94.11 \mathrm{M}\end{array}$ & [154] \\
\hline
\end{tabular}

Amp = Amperometry, BG = Brilliant Green, FcAPS = ferrocene carboxylic acid (FcA) cross-linked amino-polyethersulfone film, Fluors $=$ Fluorescence, FPS $=$ ferrocene polymer nanospheres, PAA = polyacrylamide, $\mathrm{PANI}=$ polyaniline, $\mathrm{PDDA}=$ Poly diallyldimethylammonium chloride, $\mathrm{DPV}=$ differential pulse voltammetry, PPY $=$ poly pyrrole, TBA $=55^{\prime \prime}$-terthiophene- $3^{\prime}$-p-benzoic acid.

\section{Non-Enzymatic Detection of Glucose}

Enzymeless electrochemical determination of glucose has been a dream of many researchers to overcome the drawbacks of poor stability and the high cost of GOX. In this context, considerable attempts for non-enzymatic detection of glucose using CPs, particularly, PPY and PANI, have been noticed and, in most cases, metal or metal oxides are required to effectuate in electrocatalysis (Table 4). The CPs aid in increasing the stability and enhancing the electrochemical capacity of the electrodes. In contrast, biosensors are highly specific and less vulnerable to interference, but the working conditions and stability are still major drawbacks [132]. The measurements are performed in alkaline solution, which is not very attractive to patients with diabetes mellitus, and the linear range is very narrow, falls short of the required limit of $25-30 \mathrm{mM}$. Non-specific protein binding on metal particles and conducting polymers are expected to foul the detecting surface and affect the signal response. Attempts have been made to improve the conductivity and hence sensitivity using a combination of CPs, metal, or metal oxides with carbon nanotubes or graphene. There are still formidable challenges concerning the applicability of enzymeless detection of glucose using blood [155]. Novel materials offering better electrodes and protective films with antifouling properties should be investigated to yield mature technologies applicable to the commercialization of non-enzymatic sensors. Non-specific adsorption of proteins and biomolecules is always problematic when more hydrophobic materials are present on the electrode. 
Table 4. Non-enzymatic glucose detection with conducting polymers (CPs) matrices.

\begin{tabular}{|c|c|c|c|}
\hline CPs & Metal Particles & Analytical Performance & Ref. \\
\hline Polybithiophene & Pd microparticles & $\begin{array}{l}\text { Linearity: } 0.04 \text { to } 0.4 \mathrm{mM} \\
\text { LOD: } 7 \mu \mathrm{M} \text { (under alkaline conditions) }\end{array}$ & [156] \\
\hline $\begin{array}{c}\text { Keggin } \\
\text { Polyoxometalate/MWCNTs }\end{array}$ & $\begin{array}{l}\text { Mixed-valence Co(III) } \\
\text { and Co(II) structures }\end{array}$ & $\begin{array}{l}\text { Linearity: } 0.1 \mathrm{mM} \text { to } 10.0 \mathrm{mM} \\
\text { LOD: } 1.21 \mu \mathrm{M} \text { (in } 0.1 \mathrm{M} \mathrm{NaOH})\end{array}$ & [157] \\
\hline PPY nanowire & $\begin{array}{l}\text { A nickel-cobalt-sulfide } \\
\text { nanosheet }\end{array}$ & $\begin{array}{c}\text { Two linear ranges: } 2 \mu \mathrm{M} \text { to } 140 \mu \mathrm{M} \\
0.14 \mathrm{mM} \text { to } 2 \mathrm{mM} \\
\text { LOD: } 0.82 \mu \mathrm{M} \text { (in } 0.1 \mathrm{M} \mathrm{NaOH})\end{array}$ & [158] \\
\hline $\begin{array}{l}\text { Benzoic acid-functionalized } \\
\text { poly(terthiophene) }\end{array}$ & AuNPs & $\begin{array}{c}\text { Potentiometric response (in saliva): } \\
0.32 \mu \mathrm{M}-1 \mathrm{mM} \\
\mathrm{LOD}=0.19 \mu \mathrm{M}\end{array}$ & [159] \\
\hline Poly (o-phenylenediamide) & Ag-NPs & $\begin{array}{c}\text { Linearity: } 0.15 \text { to } 13 \mathrm{mM} \\
\text { LOD: } 12 \mu \mathrm{M} \\
\text { Detecting blood glucose, } \mathrm{PBS} \mathrm{pH} 7\end{array}$ & [160] \\
\hline $\begin{array}{c}\text { Poly } \\
\text { (thieno[3-4-b]-1,4-dioxin-2-methanol) }\end{array}$ & Not required & $\begin{array}{l}\text { Linearity: } 1-9 \mathrm{mM} \\
\text { In } 0.1 \mathrm{M} \text { PBS }\end{array}$ & [161] \\
\hline PANI nanofiber & $\mathrm{NiO} / \mathrm{CuO} \mathrm{NPs}$ & $\begin{array}{l}\text { Linearity: } 20 \text { to } 2500 \mu \mathrm{M} \\
\text { LOD: } 2 \mu \mathrm{M} \text { (in } 0.1 \mathrm{M} \mathrm{NaOH} \text { ) }\end{array}$ & [162] \\
\hline PPY & $\begin{array}{c}\mathrm{ZnFe}_{2} \mathrm{O}_{4} \text { magnetic } \\
\text { nanoparticles }\end{array}$ & $\begin{array}{c}\text { Linear up to } 8 \mathrm{mM} \\
\text { LOD: } 0.1 \mathrm{mM} \text {, in). } 1 \mathrm{M} \mathrm{NaOH}\end{array}$ & [163] \\
\hline PPY nanowires & $\mathrm{CuO}-\mathrm{Cu}_{2} \mathrm{O} \mathrm{NPs}$ & $\begin{array}{c}\text { Linear up to } 8 \mathrm{mM} \\
\text { LOD: } 6.2 \mu \mathrm{M} \text { (in } 50 \mathrm{mM} \mathrm{NaOH})\end{array}$ & [164] \\
\hline Poly(3-octylthiophene) & Au NPs & $\begin{array}{l}\text { Potentiometric, Linear: } 5-30 \mathrm{mM} \text {, LOD: } \\
0.2 \mathrm{mM} \text {, in boric acid-borate buffer, } \mathrm{pH} \\
9 \text { plus } 100 \mathrm{mM} \mathrm{NaCl}\end{array}$ & [165] \\
\hline $\begin{array}{l}\text { PPY nanowire/nickel foam } \\
\text { substrate }\end{array}$ & $\mathrm{NiCO}_{2} \mathrm{O}_{4}$ & $\begin{array}{c}\mathrm{LOD}=0.22 \mu \mathrm{M} \text {, linearity: } 0.001-20 \mathrm{mM} \\
\text { (in } 0.1 \mathrm{M} \mathrm{NaOH} \text { ) }\end{array}$ & [166] \\
\hline $\begin{array}{l}\text { Conductive Polyaniline } \\
\text { Nanosheets (CPANINS) }\end{array}$ & & $\begin{array}{c}\mathrm{LOD}=0.043 \mu \mathrm{M}, \text { Linearity: } 1-1000 \mu \mathrm{M} \\
\quad\left(\text { in } 0.1 \mathrm{M} \mathrm{H}_{2} \mathrm{SO}_{4} \text { ) }\right.\end{array}$ & [167] \\
\hline PANI/MWCNTs & $\mathrm{ZnO}$ & $\begin{array}{l}\text { LOD: } 0.1 \mathrm{mM} \text {, two linear regions: } 0.1 \text { to } \\
1 \mathrm{mM} \text { and } 1 \text { to } 6 \mathrm{mM}(10 \mathrm{mM} \mathrm{NaOH})\end{array}$ & [168] \\
\hline PANI & $\mathrm{NiO}$ & LOD: $0.06 \mu \mathrm{M}$, linearity: 1-3000 $\mu \mathrm{M}$ & [169] \\
\hline
\end{tabular}

AuNPs $=$ gold nanoparticles, AgNPs $=$ silver nanoparticles, PANI $=$ polyaniline, PPY $=$ polypyrrole, MWCNT $=$ multiwalled carbon nanotubes

\section{Trends and Future Possibilities}

It has been a long journey since the discovery of CPs with a Nobel Prize awarded to three people: H. Shirakawa, A. G. MacDiarmid, and A. J. Heeger in 2000 [170]. Considerable attempts have been focused on the use of CPs as electrode materials in batteries [171]. There are still several cost and technical issues for the use of CPs in this domain, compared to optoelectronic devices [172]. Electrochemistry has advanced significantly from the pioneering concept and historical use of the mercury electrode by Heyrovsky [173]. A fundamental framework of direct electron transfer (DET) was elucidated and solidified by Marcus, another Nobel Prize winner in Chemistry [174] A search from Web of Science unravels 2500 publications related to the use of CPs for biosensing, starting with the use of two classical CPs, PANI and PPY. Other polymers have emerged and the PEDOT: PSS pair has also received attention, whereas several other CPs have not been attempted [172]. More publications related to CPs have also been supported by nanoparticles, carbon nanotubes, graphene, etc. to form polymer composites. Pertaining to the synthesis of $\mathrm{CPs}$, the polymerization of carbon dots is worth noting [175]. Conducting polymers decorated with nanoparticles such as $\mathrm{CuO}$, zinc doped $\mathrm{CuO}$ particles exhibit antimicrobial activities $[176,177]$. This feature might open the possibility for the development of implanted biosensors or enzymeless detection of glucose based on electrocatalysis of such metal oxide nanoparticles. 
In principle, biosensors are versatile tools for monitoring of a variety of analytes with significant importance in healthcare, agriculture, environment, food, and biosecurity. The confinement of a recognition molecule on highly conductive electrodes is necessary for the development of sensitive and selective biosensing. Besides glucose monitoring or pregnancy test, the commercialization of other types of biosensors is tepid, including the one for cholesterol. Even glucose biosensors encounter tough competition with non-invasive glucose monitoring systems, equipped with smartphones for data processing, storage, and transmission. Non-specific protein adsorption is always problematic and challenging, which might impede the performance of conducting polymer biosensors. Most of such biosensors have been evaluated under controlled laboratory conditions, and clean samples are spiked with various known interfering molecules. Clinical samples might contain several unknown plausible interferents, which invoke a deficiency in both specificity and selectivity of target molecules. For medical applications, the practice is merely based on single-use, so the issue of simple adsorption on the electrode or covalent coupling of the sensing biomolecule to a conducting polymer becomes very trivial. For environmental monitoring, the degradation of CPs over time is likely unavoidable. Thus, intensive research is still needed on the stability improvement of the biosensors.

The role of existing CPs and the search for new ones need to be addressed from both commercial and academic viewpoints. Pyrrole and its derivatives possess all desirable features for the fabrication of biosensors and immunosensors. In brief, they are stable under ambient conditions and polymerized under natural and aqueous media for the enzyme entrapment process in one single step. Extensive research has been conducted with PPY for the development of chemical sensors, biosensors, DNA-based sensors, and immunosensors.

A similar situation is expected for PANI with an amino group for conjugation of recognition biomolecules as this polymer has been investigated rather extensively in biosensors construction. PANI and its derivative are well-known for their semi-flexibility and high conductivity to serve as immobilization matrices for biomolecules without compromising their biological activities. It can still serve as an immobilization matrix for bioconjugation; however, it must compete with other polymers and biopolymers, including Nafion, chitosan nanocrystal, starch, nylon, cellulose nanocrystal, etc. For long-term applications, pure CPs have several shortcomings such as decreased sensitivity, reduced selectivity, surface poisoning, and other agent intrusions on their pore structures. The issue of polymer aging should be investigated carefully as it might affect the polymer matrix disorder and permselectivity, resulting in biosensors with poor analytical performances. To a certain extent, CPs can be formulated with graphene, carbon nanotubes, and metallic nanoparticles. Polymer composites could play an important role in the development of wearable and flexible high-performance sensors/biosensors.

The demand for glucose monitoring will inevitably increase significantly as 450 million cases of diabetes could reach 700 million cases in 2045 [178]. The future trend of glucose detection will focus on the different bands of glucose in the electromagnetic spectrum with the aid of advanced mathematical and statistical algorithms to improve the accuracy of glucose estimation [179]. Doubtlessly, the appearance of non-invasive glucose is emerging, and it is just a matter of time before non-invasive monitoring of glucose with acceptable accuracy and specificity is achieved. It is also questionable if continuous monitoring of glucose is needed except for critical diabetes type 1 . A comprehensive review of the performance of non-invasive, minimally invasive biosensing for glucose is available elsewhere. Accuracy, selectivity, and precision are always plausible caveats that need to be carefully investigated and solidified, a backdrop for future research endeavors. In emergency departments, clinical diagnosis of glucose, lactate, cholesterol, urea, creatine, and creatinine is performed. Thus, the trend is moving toward the development of integrated biosensors for multi-analytes detection. In this context, the stability of such integrated biosensors is more problematic since this requirement is dependent from one enzyme to another one, which creates significant obstacles to the practical applications. For successful commercialization, the enzymes must be stable for at least 6 months with unique detection selectivity. To date, glucose oxidase is the only enzyme that fulfills these 
tough requirements, and it is not surprising to see more publications with glucose detection as over 100,000 papers have been published.

The approach of using enzymeless sensing is questionable for any compound due to its lack of selectivity for the analysis of "real world" samples. One example is the detection of nitrite in food, an approved food preservative. Nitrite is a precursor of nitroamines, a suspect cancer agent, so its level is regulated at safety levels [180]. Among various methods, nitrite can be oxidized to nitrate by a gold electrode modified by AuNPs and p-aminothiophenol [181]. However, ascorbic acid, an endogenous electroactive species, is also detected to cause significant interference and must be removed by ascorbic acid oxidase if the measurement is based on simple amperometry. Differential pulse voltammetry and square wave voltammetry are more applicable in this situation, provided the potential difference between a target compound and interfering species is sufficient.

The detection of ethanol as an indicator of "driving under influence" is a common practice in many countries. Alcohol oxidase is available, and there have been several attempts with this enzyme for the detection of ethanol in liquid. However, vapor ethanol is well served by different breath analyzers, and this field has been very competitive and crowded with four different approaches: color change due to a chemical reaction, infrared spectroscopy, fuel cell technology, and combined infrared and fuel cell. There has been no significant progress in the respective biomolecule immobilization. Simple adsorption of biomolecules on insoluble supports is attributed to nonspecific hydrophobic interaction and hydrogen bonding. Entrapping biomolecules by polymers, e.g., Nafion is very effective to confine proteins on the electrode. However, bioconjugation is more commonly used to form stable covalent binding between biorecognition molecules with the support for repeated analysis. This technology is maturing, and the most used techniques are still glutaraldehyde and carbodiimide activation.

Based on the solid-phase synthesis, peptide chains with high specificity and versatility can be synthesized and custom-made to meet specific requirements. Compared to other biological materials, peptides are more stable and active for prolonged periods, compared with enzymes and antibodies. Peptides can also be designed to have specific three-dimensional structures like proteins to improve biorecognition capabilities like antibodies and enzymes. The future development of peptide-based biosensors is expected to grow significantly. Considerable demands are also expected for the detection of food and waterborne parasites. Cryptosporidium, also known as Crypto (diarrhea linked to water) and Giardia (diarrheal illness is known as giardiasis caused by a parasite) are two important targets. Besides human infection, many species of Cryptosporidium infect animals, i.e., the application of biosensors in veterinary medicine could be enormous if it is cost and performance effective, compared to immunoassays. Of importance, is the development of advancing peptide-based biorecognition elements for biosensors using in-silico evolution [182].

Recent progress in the synthesis of porous carbon materials deserves a brief discussion here because the use of these materials in biosensing is very limited. Porous carbon materials have three types of pore sizes: microporous (below $2 \mathrm{~nm}$ ), mesoporous ( $>2 \mathrm{~nm}$ and $<50 \mathrm{~nm}$ ), and macroporous (above $50 \mathrm{~nm}$ ) and can be synthesized by several different methods [183]. Porous carbon (PC) has several distinct features such as high surface areas (over $2000 \mathrm{~m}^{2} \mathrm{~g}^{-1}$ ), tunable surface chemistry, and short diffusion pathway for rapid mass transfer. Albeit PC has been used extensively in electrocatalysis, energy storage, and capacitors, its application in biosensors is very limited [184,185] PC can simply form a nanocomposite with Prussian Blue (PB) and serve as an efficient immobilization matrix for GOX toward the development of a biosensor for glucose detection [186]. As electrodes for biosensing, uniform porous carbon materials with highly graphitic structures are needed and the synthesis of such materials has been very challenging. Macroporous graphite felt and porous graphitized carbon monolith are two materials that could be used to fabricate biosensors [187] or high-performance microbial cell anodes [188]. The use of CPs with porous carbon remains to be explored, a backdrop for future research endeavors. 


\section{Conclusions}

Both PANI, PPY, two classical conducting polymers, and their derivatives have been exploited extensively towards the development of different biosensing platforms. Conducting polymer-based composites are formed by blending or mixing CPs with other materials, including metal oxide nanoparticles to achieve multifunctionality. Resulting composites benefit from the synergistic effect of different components to exhibit multi-functionalized properties with enhanced mechanical performance and processability. The interfacial adhesion between the conducting polymer and other components is attributed to composites properties, structures, and morphologies. Noble metal nanoclusters, e.g., platinum nanoclusters, can be integrated during oxidative polymerization of different monomers to form a composite with enhanced electrochemical properties, mechanical performance, and processability. Detection of immunoglobulins such as $\operatorname{IgM}, \operatorname{IgG}$, and $\operatorname{IgA}$ in response to infectious diseases, will receive considerable attention. Synthesized peptides and recombinant antigens and proteins of viruses and pathogens can be synthesized and used as biorecognition elements. CPs and their composites are anticipated to serve as excellent immobilization matrices for such biomolecules. Emerging porous carbon and carbon felt have potential applications in both chemosensing and biosensing platforms due to their high surface areas and ease of synthesis.

Author Contributions: All four authors J.H.T.L., T.N., S.S. and B.D.M. wrote the different sections of the paper. J.H.T.L. edited and mainly revised the paper. All authors have read and agreed to the published version of the manuscript.

Funding: This research received no external funding.

Acknowledgments: B.D. Malhotra is thankful to the Science and Engineering Research Board (Government of India) for the award of a Distinguished Fellowship (SB/DF/011/2019). S. Solanki acknowledges the Council of Scientific and Industrial Research (CSIR), India for the award of a research associate fellowship.

Conflicts of Interest: The authors declare no conflict of interest.

\section{References}

1. Kucherenko, I.; Soldatkin, O.; Kucherenko, D.Y.; Soldatkina, O.; Dzyadevych, S.V. Advances in nanomaterial application in enzyme-based electrochemical biosensors: A review. Nanoscale Adv. 2019, 1, 4560-4577. [CrossRef]

2. Pandey, P.; Datta, M.; Malhotra, B. Prospects of nanomaterials in biosensors. Anal. Lett. 2008, 41, $159-209$. [CrossRef]

3. Tomczykowa, M.; Plonska-Brzezinska, M.E. Conducting polymers, hydrogels and their composites: Preparation, properties and bioapplications. Polymers 2019, 11, 350. [CrossRef] [PubMed]

4. Heinze, J.; Frontana-Uribe, B.A.; Ludwigs, S. Electrochemistry of conducting polymers-Persistent models and new concepts. Chem. Rev. 2010, 110, 4724-4771. [CrossRef]

5. Kankare, J. Electronically conducting polymers: Basic methods of synthesis and characterization. Plast. Eng. N. Y. 1998, 45, 167-200.

6. Foulds, N.C.; Lowe, C.R. Enzyme entrapment in electrically conducting polymers. Immobilisation of glucose oxidase in polypyrrole and its application in amperometric glucose sensors. J. Chem. Soc. Faraday Trans. 1 Phys. Chem. Condens. Phases 1986, 82, 1259-1264. [CrossRef]

7. Umana, M.; Waller, J. Protein-modified electrodes. The glucose oxidase/polypyrrole system. Anal. Chem. 1986, 58, 2979-2983. [CrossRef]

8. Bartlett, P.; Whitaker, R. Electrochemical immobilisation of enzymes: Part II. Glucose oxidase immobilised in poly-N-methylpyrrole. J. Eectroanal. Chem. Inter. Electrochem. 1987, 224, 37-48. [CrossRef]

9. Dong, H.; Li, C.M.; Chen, W.; Zhou, Q.; Zeng, Z.X.; Luong, J.H.T. Sensitive amperometric immunosensing using polypyrrolepropylic acid films for biomolecule immobilization. Anal. Chem. 2006, 78, 7424-7431. [CrossRef]

10. Oztekin, Y.; Ramanaviciene, A.; Yazicigil, Z.; Solak, A.O.; Ramanavicius, A. Direct electron transfer from glucose oxidase immobilized on polyphenanthroline-modified glassy carbon electrode. Biosens. Bioelectron. 2011, 26, 2541-2546. [CrossRef] 
11. Kausaite-Minkstimiene, A.; Mazeiko, V.; Ramanaviciene, A.; Ramanavicius, A. Evaluation of amperometric glucose biosensors based on glucose oxidase encapsulated within enzymatically synthesized polyaniline and polypyrrole. Sens. Actuators B Chem. 2011, 158, 278-285. [CrossRef]

12. Riddick, J.; Bunger, W.; Sakano, T. Organic Solvents. In Techniques of Chemistry, 4th ed.; John Wiley Sons: Hoboken, NJ, USA, 1985; Volume II.

13. Sax, N.I.; Hawley, G.G.; Lewis, R.J. Hawley's Condensed Chemical Dictionary; Chapman-Hall: Atlanta, GA, USA, 1987.

14. Diaz, A.F.; Castillo, J.I.; Logan, J.; Lee, W.-Y. Electrochemistry of conducting polypyrrole films. J. Eectroanal. Chem. Int. Electrochem. 1981, 129, 115-132. [CrossRef]

15. Paramo, U.; Ibanez, J.G. Electrochemical modulation of the thickness of polypyrrole films by using different anionic dopants. Int. J. Electrochem. Sci. 2011, 6, 5172-5188.

16. Silk, T.; Hong, Q.; Tamm, J.; Compton, R.G. AFM studies of polypyrrole film surface morphology I. The influence of film thickness and dopant nature. Synth. Met. 1998, 93, 59-64. [CrossRef]

17. Satoh, M.; Kaneto, K.; Yoshino, K. Dependences of electrical and mechanical properties of conducting polypyrrole films on conditions of electrochemical polymerization in an aqueous medium. Synth. Met. 1986, 14, 289-296. [CrossRef]

18. Zhou, M.; Heinze, J. Electropolymerization of pyrrole and electrochemical study of polypyrrole. 3. Nature of "water effect" in acetonitrile. J. Phys. Chem. B 1999, 103, 8451-8457. [CrossRef]

19. Williams, A.; Ibrahim, I.T. Carbodiimide chemistry: Recent advances. Chem. Rev. 1981, 81, 589-636. [CrossRef]

20. McLeod, G.G.; Mahboubian-Jones, M.; Pethrick, R.A.; Watson, S.D.; Truong, N.; Galin, J.; Francois, J. Synthesis, electrochemical polymerization and properties of poly (2,5-di-(-2-thienyl)-pyrrole). Polymer 1986, 27, 455-458. [CrossRef]

21. Kim, S.; Jang, L.K.; Park, H.S.; Lee, J.Y. Electrochemical deposition of conductive and adhesive polypyrrole-dopamine films. Sci. Rep. 2016, 6, 30475. [CrossRef]

22. Ito, S.; Murata, K.; Teshima, S.; Aizawa, R.; Asako, Y.; Takahashi, K.; Hoffman, B.M. Simple synthesis of water-soluble conducting polyaniline. Synth. Met. 1998, 96, 161-163. [CrossRef]

23. Bhadra, S.; Khastgir, D.; Singha, N.K.; Lee, J.H. Progress in preparation, processing and applications of polyaniline. Prog. Polym. Sci. 2009, 34, 783-810. [CrossRef]

24. Nagarajan, R.; Tripathy, S.; Kumar, J.; Bruno, F.F.; Samuelson, L. An enzymatically synthesized conducting molecular complex of polyaniline and poly (vinylphosphonic acid). Macromolecules 2000, 33, 9542-9547. [CrossRef]

25. Wallace, G.G.; Teasdale, P.R.; Spinks, G.M.; Kane-Maguire, L.A. Conductive Electroactive Polymers: Intelligent Materials Systems; CRC Press: Boca Raton, FL, USA, 2002.

26. Zotti, G.; Cattarin, S.; Comisso, N. Electrodeposition of polythiophene, polypyrrole and polyaniline by the cyclic potential sweep method. J. Eectroanal. Chem. Int. Electrochem. 1987, 235, 259-273. [CrossRef]

27. Mu, S.; Chen, C.; Wang, J. The kinetic behavior for the electrochemical polymerization of aniline in aqueous solution. Synth. Met. 1997, 88, 249-254. [CrossRef]

28. Park, S.-M.; Lee, H.-J. Recent advances in electrochemical studies of $\pi$-conjugated polymers. Bull. Korean Chem. Soc. 2005, 26, 697-706. [CrossRef]

29. Karyakin, A.; Strakhova, A.; Yatsimirsky, A. Self-doped polyanilines electrochemically active in neutral and basic aqueous solutions: Electropolymerization of substituted anilines. J. Electroanal. Chem. 1994, 371, 259-265. [CrossRef]

30. Mu, S. Synthesis of poly (aniline-co-5-aminosalicylic acid) and its properties. Synth. Met. 2011, 161, 1306-1312. [CrossRef]

31. Obaid, A.; El-Mossalamy, E.; Al-Thabaiti, S.; El-Hallag, I.; Hermas, A.; Asiri, A. Electrodeposition and characterization of polyaniline on stainless steel surface via cyclic, convolutive voltammetry and SEM in aqueous acidic solutions. Int. J. Electrochem. Sci. 2014, 9, 1003-1015.

32. Kobayashi, T.; Yoneyama, H.; Tamura, H. Electrochemical reactions concerned with electrochromism of polyaniline film-coated electrodes. J. Eectroanal. Chem. Inter. Electrochem. 1984, 177, 281-291. [CrossRef]

33. Cesarino, I.; Moraes, F.C.; Machado, S.A. A biosensor based on polyaniline-carbon nanotube core-shell for electrochemical detection of pesticides. Electroanalysis 2011, 23, 2586-2593. [CrossRef] 
34. Shoaie, N.; Daneshpour, M.; Azimzadeh, M.; Mahshid, S.; Khoshfetrat, S.M.; Jahanpeyma, F.; Gholaminejad, A.; Omidfar, K.; Foruzandeh, M. Electrochemical sensors and biosensors based on the use of polyaniline and its nanocomposites: A review on recent advances. Microchim. Acta 2019, 186, 465. [CrossRef] [PubMed]

35. Tourillon, G.; Garnier, F. Morphology of conducting organic polymers: Polythiophene and poly (3-methyl thiophene). J. Polym. Sci. Polym. Phys. Ed. 1984, 22, 33-39. [CrossRef]

36. Aguilar-Ortíz, E.; Zaragoza-Galán, G.; Solladié, N.; Rein, R.; Aguilar-Martínez, M.; Macías-Ruvalcaba, N.; Rivera, E. Preparation and characterization of novel polythiophenes bearing oligo (ethylene glycol) spacers and porphyrin units: Optical and electrochemical properties. Synth. Met. 2012, 162, 1000-1009. [CrossRef]

37. Wang, F.; Li, M.; Wang, B.; Zhang, J.; Cheng, Y.; Liu, L.; Lv, F.; Wang, S. Synthesis and characterization of water-soluble polythiophene derivatives for cell imaging. Sci. Rep. 2015, 5, 7617. [CrossRef] [PubMed]

38. Heller, A.; Feldman, B. Electrochemical glucose sensors and their applications in diabetes management. Chem. Rev. 2008, 108, 2482-2505. [CrossRef]

39. Elgrishi, N.; Rountree, K.J.; McCarthy, B.B.; Rountree, E.S.; Eisenhart, T.T.; Dempsey, J.L. A practical beginner's guide to cyclic voltammetry. J. Chem. Educ. 2018, 95, 197-206. [CrossRef]

40. Romani, A.; Minunni, M.; Mulinacci, N.; Pinelli, P.; Vincieri, F.F.; Del Carlo, M.; Mascini, M. Comparison among differential pulse voltammetry, amperometric biosensor, and HPLC/DAD analysis for polyphenol determination. J. Agric. Food Chem. 2000, 48, 1197-1203. [CrossRef]

41. Velychko, T.P.; Soldatkin, O.O.; Melnyk, V.G.; Marchenko, S.V.; Kirdeciler, S.K.; Akata, B.; Soldatkin, A.P.; Elskaya, A.V.; Dzyadevych, S.V. A novel conductometric urea biosensor with improved analytical characteristic based on recombinant urease adsorbed on nanoparticle of silicalite. Nanoscale Res. Lett. 2016, 11, 106. [CrossRef]

42. Xiao, C.; Lachance, B.; Sunahara, G.; Luong, J.H.T. Assessment of cytotoxicity using electric cell- substrate impedance sensing: Concentration and time response function approach. Anal. Chem. 2002, 74, 5748-5753. [CrossRef]

43. Male, K.B.; Lachance, B.; Hrapovic, S.; Sunahara, G.; Luong, J.H.T. Assessment of cytotoxicity of quantum dots and gold nanoparticles using cell-based impedance spectroscopy. Anal. Chem. 2018, 80, 5487-5493. [CrossRef]

44. Allen, J.B.; Faulkner, L.R. Electrochemical Methods Fundamentals and Applications, 2nd ed.; John Wiley \& Sons: Hoboken, NJ, USA, 2001.

45. Ronkainen, N.J.; Halsall, H.B.; Heineman, W.R. Electrochemical biosensors. Chem. Soc. Rev. 2010, 39, 1747-1763. [CrossRef] [PubMed]

46. Scouten, W.H.; Luong, J.H.T.; Brown, R.S. Enzyme or protein immobilization techniques for applications in biosensor design. Trends Biotechnol. 1995, 13, 178-185. [CrossRef]

47. Welch, M.E.; Doublet, T.; Bernard, C.; Malliaras, G.G.; Ober, C.K. A glucose sensor via stable immobilization of the GOx enzyme on an organic transistor using a polymer brush. Polym. Chem. Sci. A Polym. Chem. 2015, 53, 372-377. [CrossRef]

48. Gu, H.; Xiao, X.D.; Loh, K.P. Electrochemical impedance sensing of DNA hybridization on conducting polymer film-modified diamond. J. Phys. Chem. B 2005, 109, 13611-13618. [CrossRef]

49. Setti, L.; Fraleoni-Morgera, A.; Mencarelli, I.; Filippini, A.; Ballarin, B.; Di Biase, M. An HRP-based amperometric biosensor fabricated by thermal inkjet printing. Sens. Actuators B Chem. 2007, 126, 252-257. [CrossRef]

50. Safavi, A.; Maleki, N.; Farjami, E. Fabrication of a glucose sensor based on a novel nanocomposite electrode. Biosens. Bioelectron. 2009, 24, 1655-1660. [CrossRef]

51. Derkus, B. Applying the miniaturization technologies for biosensor design. Biosens. Bioelectron. 2016, 79, 736-741. [CrossRef]

52. Wilson, G.S.; Gifford, R. Biosensors for real-time in vivo measurements. Biosens. Bioelectron. 2005, 20, 2388-2403. [CrossRef]

53. Mello, H.; Mulato, M. Enzymatically functionalized polyaniline thin films produced with one-step electrochemical immobilization and its application in glucose and urea potentiometric biosensors. Biomed. Microdevices 2020, 22, 22. [CrossRef] 
54. Erol, E.; Yildirim, E.; Cete, S. Construction of biosensor for hypoxanthine determination by immobilization of xanthine oxidase and uricase in polypyrrole-paratoluenesulfonate film. J. Solid State Electrochem. 2020, 24, 1695-1707. [CrossRef]

55. Nessark, F.; Eissa, M.; Baraket, A.; Zine, N.; Nessark, B.; Zouaoui, A.; Bausells, J.; Errachid, A. Capacitance polypyrrole-based impedimetric immunosensor for interleukin-10 cytokine detection. Electroanalysis 2020, 32, 1795-1806. [CrossRef]

56. Kumar, S.; Umar, M.; Saifi, A.; Kumar, S.; Augustine, S.; Srivastava, S.; Malhotra, B.D. Electrochemical paper based cancer biosensor using iron oxide nanoparticles decorated PEDOT: PSS. Anal. Chim. Acta 2019, 1056, 135-145. [CrossRef] [PubMed]

57. Kumar, S.; Kumar, S.; Srivastava, S.; Yadav, B.K.; Lee, S.H.; Sharma, J.G.; Doval, D.C.; Malhotra, B.D. Reduced graphene oxide modified smart conducting paper for cancer biosensor. Biosens. Bioelectron. 2015, 73, 114-122. [CrossRef]

58. Spychalska, K.; Zając, D.; Cabaj, J. Electrochemical biosensor for detection of $17 \beta$-estradiol using semi-conducting polymer and horseradish peroxidase. RSC Adv. 2020, 10, 9079-9087. [CrossRef]

59. Baluta, S.; Świst, A.; Cabaj, J.; Malecha, K. Point-of-care testing-biosensor for norepinephrine determination. Int. J. Electron. Telecommun. 2020, 66, 369-372.

60. Goda, T.; Miyahara, Y. Electrodeposition of Zwitterionic PEDOT films for conducting and antifouling surfaces. Langmuir 2019, 35, 1126-1133. [CrossRef]

61. Wang, J.; Wang, D.; Hui, N. A low fouling electrochemical biosensor based on the zwitterionic polypeptide doped conducting polymer PEDOT for breast cancer marker BRCA1 detection. Bioelectrochemistry 2020, 136, 107595. [CrossRef]

62. Dabrowski, M.; Lach, P.; Cieplak, M.; Kutner, W. Nanostructured molecularly imprinted polymers for protein chemosensing. Biosens. Bioelectron. 2018, 102, 17-26. [CrossRef]

63. Ayankojo, A.G.; Reut, J.; Opik, A.; Furchner, A.; Syritski, V. Hybrid molecularly imprinted polymer for amoxicillin detection. Biosens. Bioelectron. 2018, 118, 102-107. [CrossRef]

64. Waffo, A.; Yesildag, C.; Caserta, G.; Katz, S.; Zebger, I.; Lensen, M.; Wollenberger, U.; Scheller, F.; Altintas, Z. Fully electrochemical MIP sensor for artemisinin. Sens. Actuators B Chem. 2018, 275, 163-173. [CrossRef]

65. Kane-Maguire, L.A.; Wallace, G.G. Chiral conducting polymers. Chem. Soc. Rev. 2010, 39, $2545-2576$. [CrossRef] [PubMed]

66. Shang, X.; Song, I.; Jung, G.Y.; Choi, W.; Ohtsu, H.; Lee, J.H.; Koo, J.Y.; Liu, B.; Ahn, J.; Kawano, M. Chiral self-sorted multifunctional supramolecular biocoordination polymers and their applications in sensors. Nat. Commun. 2018, 9, 1-12. [CrossRef] [PubMed]

67. Lee, K.M.; Kim, K.H.; Yoon, H.; Kim, H. Chemical design of functional polymer structures for biosensors: From nanoscale to macroscale. Polymers 2018, 10, 551. [CrossRef] [PubMed]

68. Naficy, S.; Oveissi, F.; Patrick, B.; Schindeler, A.; Dehghani, F. Printed, flexible pH sensor hydrogels for wet environments. Adv. Mater. Technol. 2018, 3, 1800137. [CrossRef]

69. Culver, H.R.; Wechsler, M.E.; Peppas, N.A. Label-free detection of tear biomarkers using hydrogel-coated gold nanoshells in a localized surface plasmon resonance-based biosensor. ACS Nano 2018, 12, 9342-9354. [CrossRef] [PubMed]

70. Li, L.; Pan, L.; Ma, Z.; Yan, K.; Cheng, W.; Shi, Y.; Yu, G. All inkjet-printed amperometric multiplexed biosensors based on nanostructured conductive hydrogel electrodes. Nano Lett. 2018, 18, 3322-3327. [CrossRef]

71. Meng, L.; Turner, A.P.; Mak, W.C. Tunable 3D nanofibrous and bio-functionalised PEDOT network explored as a conducting polymer-based biosensor. Biosens. Bioelectron. 2020, 159, 112181. [CrossRef]

72. Słoniewska, A.; Kasztelan, M.; Berbeć, S.; Pałys, B. Influence of buffer solution on structure and electrochemical properties of poly (3, 4-ethylenedioxythiophene)/poly (styrenesulfonate) hydrogels. Synth. Met. 2020, 263, 116363. [CrossRef]

73. Cete, S.; Ozyurt, M.; Yildirim, E.; Akin, D. A novel biosensor with the use of polypyrrole-poly (sodium-4-styrenesulphonate) as a dopant in the determination of glucose. Chem. Pap. 2020, 74, 799-808. [CrossRef]

74. Kajisa, T.; Li, W.; Michinobu, T.; Sakata, T. Well-designed dopamine-imprinted polymer interface for selective and quantitative dopamine detection among catecholamines using a potentiometric biosensor. Biosens. Bioelectron. 2018, 117, 810-817. [CrossRef] 
75. Ashley, J.; Feng, X.; Sun, Y. A multifunctional molecularly imprinted polymer-based biosensor for direct detection of doxycycline in food samples. Talanta 2018, 182, 49-54. [CrossRef] [PubMed]

76. Ribeiro, J.; Pereira, C.; Silva, A.; Sales, M.G.F. Disposable electrochemical detection of breast cancer tumour marker CA 15-3 using poly (toluidine blue) as imprinted polymer receptor. Biosens. Bioelectron. 2018, 109, 246-254. [CrossRef] [PubMed]

77. Palladino, P.; Minunni, M.; Scarano, S. Cardiac Troponin T capture and detection in real-time via epitope-imprinted polymer and optical biosensing. Biosens. Bioelectron. 2018, 106, 93-98. [CrossRef]

78. Roushani, M.; Nezhadali, A.; Jalilian, Z. An electrochemical chlorpyrifos aptasensor based on the use of a glassy carbon electrode modified with an electropolymerized aptamer-imprinted polymer and gold nanorods. Microchim. Acta 2018, 185, 551. [CrossRef] [PubMed]

79. Liu, S.; Ma, Y.; Cui, M.; Luo, X. Enhanced electrochemical biosensing of alpha-fetoprotein based on three-dimensional macroporous conducting polymer polyaniline. Sens. Actuators B Chem. 2018, 255, 2568-2574. [CrossRef]

80. Lin, Z.T.; Li, Y.; Gu, J.; Wang, H.; Zhu, Z.; Hong, X.; Zhang, Z.; Lu, Q.; Qiu, J.; Wang, X. A conductive nanowire-mesh biosensor for ultrasensitive detection of serum c-reactive protein in melanoma. Adv. Funct. Mater. 2018, 28, 1802482. [CrossRef]

81. Wei, Y.; Zeng, Q.; Hu, Q.; Wang, M.; Tao, J.; Wang, L. Self-cleaned electrochemical protein imprinting biosensor basing on a thermo-responsive memory hydrogel. Biosens. Bioelectron. 2018, 99, 136-141. [CrossRef]

82. Ekomo, V.M.; Branger, C.; Bikanga, R.; Florea, A.M.; Istamboulie, G.; Calas-Blanchard, C.; Noguer, T.; Sarbu, A.; Brisset, H. Detection of Bisphenol A in aqueous medium by screen printed carbon electrodes incorporating electrochemical molecularly imprinted polymers. Biosens. Bioelectron. 2018, 112, 156-161. [CrossRef]

83. Meng, L.; Turner, A.P.F.; Mak, W.C. Positively-charged hierarchical PEDOT interface with enhanced electrode kinetics for NADH-based biosensors. Biosens. Bioelectron. 2018, 120, 115-121. [CrossRef]

84. Kuralay, F.; Dukar, N.; Bayramli, Y. Poly-L-lysine coated surfaces for ultrasensitive nucleic acid detection. Electroanalysis 2018, 30, 1556-1565. [CrossRef]

85. Moreira, F.T.; Truta, L.A.; Sales, M.G.F. Biomimetic materials assembled on a photovoltaic cell as a novel biosensing approach to cancer biomarker detection. Sci. Rep. 2018, 8, 1-11. [CrossRef] [PubMed]

86. Kausaite-Minkstimiene, A.; Glumbokaite, L.; Ramanaviciene, A.; Dauksaite, E.; Ramanavicius, A. An amperometric glucose biosensor based on poly (pyrrole-2-carboxylic acid)/glucose oxidase biocomposite. Electroanalysis 2018, 30, 1642-1652. [CrossRef]

87. Wu, H.; Lee, C.J.; Wang, H.; Hu, Y.; Young, M.; Han, Y.; Xu, F.J.; Cong, H.; Cheng, G. Highly sensitive and stable zwitterionic poly (sulfobetaine-3,4-ethylenedioxythiophene) (PSBEDOT) glucose biosensor. Chem. Sci. 2018, 9, 2540-2546. [CrossRef] [PubMed]

88. Soganci, T.; Soyleyici, H.C.; Demirkol, D.O.; Ak, M.; Timur, S. Use of super-structural conducting polymer as functional immobilization matrix in biosensor design. J. Electrochem. Soc. 2018, 165, B22. [CrossRef]

89. Apetrei, R.-M.; Cârâc, G.; Bahrim, G.; Camurlu, P. Sensitivity enhancement for microbial biosensors through cell Self-Coating with polypyrrole. Int. J. Polym. Mater. Polym. Biomater. 2018, 68, 1058-1067. [CrossRef]

90. Apetrei, R.-M.; Cârâc, G.; Bahrim, G.; Camurlu, P. Utilization of enzyme extract self-encapsulated within polypyrrole in sensitive detection of catechol. Enzym. Microb. Technol. 2019, 128, 34-39. [CrossRef]

91. Jakhar, P.; Shukla, M.; Singh, V. Electrochemically synthesized polypyrrole nanofibers towards glucose biosensing application. In Proceedings of the International Workshop on the Physics of Semiconductor and Devices, Delhi, India, 12-15 December 2017; pp. 871-874.

92. Soylemez, S.; Bekmezci, S.A.; Goker, S.; Toppare, L. Fabrication of a novel polymeric scaffold for amperometric laccase biosensor. J. Polym. Sci. Part A Polym. Chem. 2019, 57, 2333-2339. [CrossRef]

93. Li, J.; Bi, X.; Tamulevičius, S.; Erts, D.; Chang, C.-F.; Gu, Y. Fabrication of a biocompatible and continuous glucose biosensor with the poly (3, 4-ethylenedioxythiophene) modified electrode. J. Taiwan Inst. Chem. Eng. 2019, 104, 1-7. [CrossRef]

94. Cevik, E.; Cerit, A.; Tombuloglu, H.; Sabit, H.; Yildiz, H.B. Electrochemical glucose biosensors: Whole cell microbial and enzymatic determination based on 10-(4H-dithieno [3,2-b:2', 3'-d] pyrrol-4-yl)decan-1-amine interfaced glassy carbon electrodes. Anal. Lett. 2019, 52, 1138-1152. [CrossRef]

95. Ranjbar, S.; Nejad, M.A.F.; Parolo, C.; Shahrokhian, S.; Merkoçi, A. Smart chip for visual detection of bacteria using the electrochromic properties of polyaniline. Anal. Chem. 2019, 91, 14960-14966. [CrossRef] 
96. Hosseinian, M.; Najafpour, G.; Rahimpour, A. Amperometric urea biosensor based on immobilized urease on polypyrrole and macroporous polypyrrole modified Pt electrode. Turk. J. Chem. 2019, 43, 1063-1074. [CrossRef]

97. Fenoy, G.E.; Marmisolle, W.A.; Azzaroni, O.; Knoll, W. Acetylcholine biosensor based on the electrochemical functionalization of graphene field-effect transistors. Biosens. Bioelectron. 2020, 148, 111796. [CrossRef] [PubMed]

98. Gülercan, D.; Gergin, İ.; Sarac, A.S. Preparation and Electrochemical Performances of graphene oxide/PEDOT and reduced graphene oxide/PEDOT nanofibers and nanocomposites. Fibers Polym. 2018, 19, 2178-2187. [CrossRef]

99. Hussain, K.K.; Gurudatt, N.; Akhtar, M.H.; Seo, K.-D.; Park, D.-S.; Shim, Y.-B. Nano-biosensor for the in vitro lactate detection using bi-functionalized conducting polymer/N, S-doped carbon; the effect of $\alpha \mathrm{CHC}$ inhibitor on lactate level in cancer cell lines. Biosens. Bioelectron. 2020, 155, 112094. [CrossRef]

100. Seo, K.-D.; Hossain, M.M.; Gurudatt, N.; Choi, C.S.; Shiddiky, M.J.; Park, D.-S.; Shim, Y.-B. Microfluidic neurotransmitters sensor in blood plasma with mediator-immobilized conducting polymer/N, S-doped porous carbon composite. Sens. Actuators B Chem. 2020, 313, 128017. [CrossRef]

101. Ma, L.; Zhou, L.; He, Y.; Wang, L.; Huang, Z.; Jiang, Y.; Gao, J. Hierarchical nanocomposites with an $\mathrm{N}$-doped carbon shell and bimetal core: Novel enzyme nanocarriers for electrochemical pesticide detection. Biosens. Bioelectron. 2018, 121, 166-173. [CrossRef]

102. Zheng, W.; Wu, H.; Jiang, Y.; Xu, J.; Li, X.; Zhang, W.; Qiu, F. A molecularly-imprinted-electrochemical-sensor modified with nano-carbon-dots with high sensitivity and selectivity for rapid determination of glucose. Anal. Biochem. 2018, 555, 42-49. [CrossRef]

103. Zhou, Z.; Zhang, Y.; Shen, Y.; Liu, S.; Zhang, Y. Molecular engineering of polymeric carbon nitride: Advancing applications from photocatalysis to biosensing and more. Chem. Soc. Rev. 2018, 47, 2298-2321. [CrossRef]

104. Yan, K.; Yang, Y.; Zhang, J. A self-powered sensor based on molecularly imprinted polymer-coupled graphitic carbon nitride photoanode for selective detection of bisphenol A. Sens. Actuators B Chem. 2018, 259, 394-401. [CrossRef]

105. Han, R.; Wang, G.; Xu, Z.; Zhang, L.; Li, Q.; Han, Y.; Luo, X. Designed antifouling peptides planted in conducting polymers through controlled partial doping for electrochemical detection of biomarkers in human serum. Biosens. Bioelectron. 2020, 164, 112317. [CrossRef]

106. Yilmaz, Y.Y.; Yalcinkaya, E.E.; Demirkol, D.O.; Timur, S. 4-aminothiophenol-intercalated montmorillonite: Organic-inorganic hybrid material as an immobilization support for biosensors. Sens. Actuators B Chem. 2020, 307, 127665. [CrossRef]

107. Phongphut, A.; Chayasombat, B.; Cass, A.E.; Sirisuk, A.; Phisalaphong, M.; Prichanont, S.; Thanachayanont, C. Clay/au nanoparticle composites as acetylcholinesterase carriers and modified-electrode materials: A comparative study. Appl. Clay Sci. 2020, 194, 105704. [CrossRef]

108. Zheng, H.; Liu, M.; Yan, Z.; Chen, J. Highly selective and stable glucose biosensor based on incorporation of platinum nanoparticles into polyaniline-montmorillonite hybrid composites. Microchem. J. 2020, 152, 104266. [CrossRef]

109. Erkmen, C.; Kurbanoglu, S.; Uslu, B. Fabrication of poly (3,4-ethylenedioxythiophene)-iridium oxide nanocomposite based tyrosinase biosensor for the dual detection of catechol and azinphos methyl. Sens. Actuators B Chem. 2020, 316, 128121. [CrossRef]

110. Altun, A.; Apetreia, R.M.; Camurlu, P. Reagentless amperometric glucose biosensors: Ferrocene-tethering and copolymerization. J. Electrochem. Soc. 2020, 167, 107507. [CrossRef]

111. Sun, Y.; Zeng, W.; Sun, H.; Luo, S.; Chen, D.; Chan, V.; Liao, K. Inorganic/polymer-graphene hybrid gel as versatile electrochemical platform for electrochemical capacitor and biosensor. Carbon 2018, 132, 589-597. [CrossRef]

112. Wang, X.; Zhu, Y.; Olsen, T.R.; Sun, N.; Zhang, W.; Pei, R.; Lin, Q. A graphene aptasensor for biomarker detection in human serum. Electrochim. Acta 2018, 290, 356-363. [CrossRef]

113. Fusco, G.; Gobel, G.; Zanoni, R.; Bracciale, M.P.; Favero, G.; Mazzei, F.; Lisdat, F. Aqueous polythiophene electrosynthesis: A new route to an efficient electrode coupling of PQQ-dependent glucose dehydrogenase for sensing and bioenergetic applications. Biosens. Bioelectron. 2018, 112, 8-17. [CrossRef] 
114. Gautam, V.; Singh, K.P.; Yadav, V.L. Polyaniline/MWCNTs/starch modified carbon paste electrode for non-enzymatic detection of cholesterol: Application to real sample (cow milk). Anal. Bioanal. Chem. 2018, 410, 2173-2181. [CrossRef]

115. Liu, Y.; Turner, A.P.F.; Zhao, M.; Mak, W.C. Processable enzyme-hybrid conductive polymer composites for electrochemical biosensing. Biosens. Bioelectron. 2018, 100, 374-381. [CrossRef]

116. Nguyet, N.T.; Van Thu, V.; Lan, H.; Trung, T.; Le, A.-T.; Pham, V.-H.; Tam, P.D. Simple label-free dna sensor based on $\mathrm{CeO}_{2}$ nanorods decorated with ppy nanoparticles. J. Electron. Mater. 2019, 48, 6231-6239. [CrossRef]

117. Yang, T.; Ren, X.; Yang, M.; Li, X.; He, K.; Rao, A.; Wan, Y.; Yang, H.; Wang, S.; Luo, Z. A highly sensitive label-free electrochemical immunosensor based on poly (indole-5-carboxylicacid) with ultra-high redox stability. Biosens. Bioelectron. 2019, 141, 111406. [CrossRef] [PubMed]

118. Thunyakontirakun, W.; Sriwichai, S.; Phanichphant, S.; Janmanee, R. Fabrication of poly (pyrrole-3-carboxylic acid)/graphene oxide composite thin film for glucose biosensor. Mater. Today Proc. 2019, 17, 2070-2077. [CrossRef]

119. Mousa, H.M.; Aggas, J.R.; Guiseppi-Elie, A. Electropolymerization of aniline and (N-phenyl-o-phenylenediamine) for glucose biosensor application. Mater. Lett. 2019, 238, 267-270. [CrossRef]

120. Salazar, P.; Martín, M.; González-Mora, J.L. In situ electrodeposition of cholesterol oxidase-modified polydopamine thin film on nanostructured screen printed electrodes for free cholesterol determination. J. Electroanal. Chem. 2019, 837, 191-199. [CrossRef]

121. Wang, J.; Hui, N. Electrochemical functionalization of polypyrrole nanowires for the development of ultrasensitive biosensors for detecting microRNA. Sens. Actuators B Chem. 2019, 281, 478-485. [CrossRef]

122. Abd-Wahab, F.; Abdul Guthoos, H.F.; Wan Salim, W.W.A. Solid-state rGO-PEDOT: PSS transducing material for cost-effective enzymatic sensing. Biosensors 2019, 9, 36. [CrossRef]

123. Sahyar, B.Y.; Kaplan, M.; Ozsoz, M.; Celik, E.; Otles, S. Electrochemical xanthine detection by enzymatic method based on Ag doped ZnO nanoparticles by using polypyrrole. Bioelectrochemistry 2019, 130, 107327. [CrossRef]

124. Altun, A.; Apetrei, R.M.; Camurlu, P. The effect of copolymerization and carbon nanoelements on the performance of poly (2,5-di(thienyl)pyrrole) biosensors. Mater. Sci. Eng. C Mater. Biol. Appl. 2019, 105, 110069. [CrossRef]

125. Yashas, S.R.; Sandeep, S.; Shivakumar, B.P.; Swamy, N.K. A matrix of perovskite micro-seeds and polypyrrole nanotubes tethered laccase/graphite biosensor for sensitive quantification of 2,4-dichlorophenol in wastewater. Anal. Methods 2019, 11, 4511-4519. [CrossRef]

126. Ahmad, L.; Salmon, L.; Korri-Youssoufi, H. Electrochemical detection of the human cancer biomarker 'autocrine motility factor-phosphoglucose isomerase' based on a biosensor formed with a monosaccharidic inhibitor. Sens. Actuators B Chem. 2019, 299, 126933. [CrossRef]

127. Aghamiri, Z.S.; Mohsennia, M.; Rafiee-Pour, H.-A. Immobilization of cytochrome C on polyaniline/polypyrrole/carboxylated multi-walled carbon nanotube/glassy carbon electrode: Biosensor fabrication. J. Solid State Electrochem. 2019, 23, 2233-2242. [CrossRef]

128. Almeida, L.C.; Correia, R.D.; Marta, A.; Squillaci, G.; Morana, A.; La Cara, F.; Correia, J.P.; Viana, A.S. Electrosynthesis of polydopamine films-tailored matrices for laccase-based biosensors. Appl. Surf. Sci. 2019, 480, 979-989. [CrossRef]

129. Phetsang, S.; Jakmunee, J.; Mungkornasawakul, P.; Laocharoensuk, R.; Ounnunkad, K. Sensitive amperometric biosensors for detection of glucose and cholesterol using a platinum/reduced graphene oxide/poly (3-aminobenzoic acid) film-modified screen-printed carbon electrode. Bioelectrochemistry 2019, 127, 125-135. [CrossRef] [PubMed]

130. Nguyen, T.N.; Nolan, J.K.; Park, H.; Lam, S.; Fattah, M.; Page, J.C.; Joe, H.-E.; Jun, M.B.; Lee, H.; Kim, S.J. Facile fabrication of flexible glutamate biosensor using direct writing of platinum nanoparticle-based nanocomposite ink. Biosens. Bioelectron. 2019, 131, 257-266. [CrossRef] [PubMed]

131. Gupta, A.; Bhardwaj, S.K.; Sharma, A.L.; Kim, K.-H.; Deep, A. Development of an advanced electrochemical biosensing platform for E. coli using hybrid metal-organic framework/polyaniline composite. Environ. Res. 2019, 171, 395-402. [CrossRef] 
132. Lee, W.C.; Kim, K.B.; Gurudatt, N.G.; Hussain, K.K.; Choi, C.S.; Park, D.S.; Shim, Y.B. Comparison of enzymatic and non-enzymatic glucose sensors based on hierarchical $\mathrm{Au}-\mathrm{Ni}$ alloy with conductive polymer. Biosens. Bioelectron. 2019, 130, 48-54. [CrossRef]

133. Almeida, L.; Correia, R.; Squillaci, G.; Morana, A.; La Cara, F.; Correia, J.; Viana, A. Electrochemical deposition of bio-inspired laccase-polydopamine films for phenolic sensors. Electrochim. Acta 2019, 319, 462-471. [CrossRef]

134. Maity, D.; Minitha, C.R.; Rajendra Kumar, R.T. Glucose oxidase immobilized amine terminated multiwall carbon nanotubes/reduced graphene oxide/polyaniline/gold nanoparticles modified screen-printed carbon electrode for highly sensitive amperometric glucose detection. Mater. Sci. Eng. C-Mater. Biol. Appl. 2019, 105, 110075. [CrossRef]

135. Keteklahijani, Y.Z.; Sharif, F.; Roberts, E.P.; Sundararaj, U. Enhanced sensitivity of dopamine biosensors: An electrochemical approach based on nanocomposite electrodes comprising polyaniline, nitrogen-doped graphene, and DNA-functionalized carbon nanotubes. J. Electrochem. Soc. 2019, 166, B1415. [CrossRef]

136. Li, Z.; Yin, J.; Gao, C.; Qiu, G.; Meng, A.; Li, Q. The construction of electrochemical aptasensor based on coral-like poly-aniline and Au nano-particles for the sensitive detection of prostate specific antigen. Sens. Actuators B Chem. 2019, 295, 93-100. [CrossRef]

137. Al-Sagur, H.; Shanmuga Sundaram, K.; Kaya, E.N.; Durmus, M.; Basova, T.V.; Hassan, A. Amperometric glucose biosensing performance of a novel graphene nanoplatelets-iron phthalocyanine incorporated conducting hydrogel. Biosens. Bioelectron. 2019, 139, 111323. [CrossRef] [PubMed]

138. Alim, S.; Kafi, A.K.M.; Rajan, J.; Yusoff, M.M. Application of polymerized multiporous nanofiber of $\mathrm{SnO}_{2}$ for designing a bienzyme glucose biosensor based on HRP/GOx. Int. J. Biol. Macromol. 2019, 123, 1028-1034. [CrossRef] [PubMed]

139. Guo, X.; Li, Y.; Li, Y.; Ye, Z.; Zhang, J.; Zhu, T.; Li, F. An L012@ PAni-PAAm hydrogel composite based-electrochemiluminescence biosensor for in situ detection of $\mathrm{H}_{2} \mathrm{O}_{2}$ released from cardiomyocytes. Electrochim. Acta 2020, 354, 136763. [CrossRef]

140. Khoder, R.; Korri-Youssoufi, H. E-DNA biosensors of M. tuberculosis based on nanostructured polypyrrole. Mater. Sci. Eng. C Mater. Biol. Appl. 2020, 108, 110371. [CrossRef]

141. Aydin, M.; Aydin, E.B.; Sezginturk, M.K. A highly selective electrochemical immunosensor based on conductive carbon black and star PGMA polymer composite material for IL-8 biomarker detection in human serum and saliva. Biosens. Bioelectron. 2018, 117, 720-728. [CrossRef]

142. He, L.; Cui, B.; Liu, J.; Song, Y.; Wang, M.; Peng, D.; Zhang, Z. Novel electrochemical biosensor based on core-shell nanostructured composite of hollow carbon spheres and polyaniline for sensitively detecting malathion. Sens. Actuators B Chem. 2018, 258, 813-821. [CrossRef]

143. Tancharoen, C.; Sukjee, W.; Thepparit, C.; Jaimipuk, T.; Auewarakul, P.; Thitithanyanont, A.; Sangma, C. Electrochemical biosensor based on surface imprinting for zika virus detection in serum. ACS Sens. 2018, 4, 69-75. [CrossRef]

144. Yang, J.; Liu, Y.; Liu, S.; Li, L.; Zhang, C.; Liu, T. Conducting polymer composites: Material synthesis and applications in electrochemical capacitive energy storage. Mater. Chem. Front. 2017, 1, 251-268. [CrossRef]

145. Liu, Y.; Lu, N.; Poyraz, S.; Wang, X.; Yu, Y.; Scott, J.; Smith, J.; Kim, M.J.; Zhang, X. One-pot formation of multifunctional Pt-conducting polymer intercalated nanostructures. Nanoscale 2013, 5, 3872-3879. [CrossRef]

146. Shahrokhian, S.; Shamloofard, M.; Salimian, R. Investigation of the electrochemical behavior of tizanidine on the surface of glassy carbon electrode modified with multi-walled carbon nanotube/titan yellow-doped polypyrrole. J. Electroanal. Chem. 2018, 823, 146-154. [CrossRef]

147. Kirankumar, R.; Huang, W.-C.; Chen, H.-F.; Chen, P.-Y. Electropolymerization and characterization of carbazole substituted viologen conducting polymers: The effects of electrolytes and potential applications of the polymers. J. Electroanal. Chem. 2018, 826, 198-206. [CrossRef]

148. Kotanen, C.N.; Karunwi, O.; Alam, F.; Uyehara, C.F.; Guiseppi-Elie, A. Fabrication and in vitro performance of a dual responsive lactate and glucose biosensor. Electrochim. Acta 2018, 267, 71-79. [CrossRef]

149. Phonklam, K.; Wannapob, R.; Sriwimol, W.; Thavarungkul, P.; Phairatana, T. A novel molecularly imprinted polymer PMB/MWCNTs sensor for highly-sensitive cardiac troponin T detection. Sens. Actuators B Chem. 2020, 308, 127630. [CrossRef] 
150. Liu, S.; Su, W.; Li, Y.; Zhang, L.; Ding, X. Manufacturing of an electrochemical biosensing platform based on hybrid DNA hydrogel: Taking lung cancer-specific miR-21 as an example. Biosens. Bioelectron. 2018, 103, 1-5. [CrossRef]

151. Maiga, M.; Yazgan, I.; Kariuki, V.M.; Demirkol, D.O.; Sadik, O.A.; Timur, S. Brilliant green sequestered poly (amic) acid film for dual-mode detection: Fluorescence and electrochemical enzymatic biosensor. Sens. Actuators B Chem. 2018, 256, 71-78. [CrossRef]

152. Mattoussi, M.; Matoussi, F.; Raouafi, N. Non-enzymatic amperometric sensor for hydrogen peroxide detection based on a ferrocene-containing cross-linked redox-active polymer. Sens. Actuators B Chem. 2018, 274, 412-418. [CrossRef]

153. Chen, Y.; Liu, X.; Wu, T.; Hou, W.; Liu, M.; Zhang, Y.; Yao, S. Enhanced electrochemical sensitivity towards acetaminophen determination using electroactive self-assembled ferrocene derivative polymer nanospheres with multi-walled carbon nanotubes. Electrochim. Acta 2018, 272, 212-220. [CrossRef]

154. Albayati, S.A.R.; Kashanian, S.; Nazari, M.; Rezaei, S. Novel fabrication of a laccase biosensor to detect phenolic compounds using a carboxylated multiwalled carbon nanotube on the electropolymerized support. Bull. Mater. Sci. 2019, 42, 187. [CrossRef]

155. Kailasa, S.; Rani, B.G.; Reddy, M.S.B.; Jayarambabu, N.; Munindra, P.; Sharma, S.; Rao, K.V. $\mathrm{NiO}$ nanoparticles-decorated conductive polyaniline nanosheets for amperometric glucose biosensor. Mater. Chem. Phys. 2020, 242, 122524. [CrossRef]

156. Hwang, D.W.; Lee, S.; Seo, M.; Chung, T.D. Recent advances in electrochemical non-enzymatic glucose sensors-A review. Anal. Chim. Acta 2018, 1033, 1-34. [CrossRef] [PubMed]

157. Lamiri, L.; Belgherbi, O.; Dehchar, C.; Laidoudi, S.; Tounsi, A.; Nessark, B.; Habelhames, F.; Hamam, A.; Gourari, B. Performance of polybithiophene-palladium particles modified electrode for non-enzymatic glucose detection. Synth. Met. 2020, 266, 116437. [CrossRef]

158. Ayranci, R.; Torlak, Y.; Ak, M. Non-Enzymatic Electrochemical detection of glucose by mixed-valence cobalt containing keggin polyoxometalate/multi-walled carbon nanotube composite. J. Electroanal. Chem. 2019, 166, B205. [CrossRef]

159. Dai, H.; Cao, P.; Chen, D.; Li, Y.; Wang, N.; Ma, H.; Lin, M. Ni-Co-S/PPy core-shell nanohybrid on nickel foam as a non-enzymatic electrochemical glucose sensor. Synth. Met. 2018, 235, 97-102. [CrossRef]

160. Kim, D.-M.; Moon, J.-M.; Lee, W.-C.; Yoon, J.-H.; Choi, C.S.; Shim, Y.-B. A potentiometric non-enzymatic glucose sensor using a molecularly imprinted layer bonded on a conducting polymer. Biosens. Bioelectron. 2017, 91, 276-283. [CrossRef]

161. Wang, J.; Wang, M.; Guan, J.; Wang, C.; Wang, G. Construction of a non-enzymatic sensor based on the poly (o-phenylenediamine)/Ag-NPs composites for detecting glucose in blood. Mater. Sci. Eng. C 2017, 71, 844-851. [CrossRef]

162. Hocevar, M.A.; Fabregat, G.; Armelin, E.; Ferreira, C.A.; Alemán, C. Nanometric polythiophene films with electrocatalytic activity for non-enzymatic detection of glucose. Eur. Polym. J. 2016, 79, 132-139. [CrossRef]

163. Ghanbari, K.; Babaei, Z. Fabrication and characterization of non-enzymatic glucose sensor based on ternary $\mathrm{NiO} / \mathrm{CuO} /$ polyaniline nanocomposite. Anal. Biochem. 2016, 498, 37-46. [CrossRef]

164. Shahnavaz, Z.; Lorestani, F.; Alias, Y.; Woi, P.M. Polypyrrole- $\mathrm{ZnFe}_{2} \mathrm{O}_{4}$ magnetic nano-composite with core-shell structure for glucose sensing. Appl. Surf. Sci. 2014, 317, 622-629. [CrossRef]

165. Meng, F.; Shi, W.; Sun, Y.; Zhu, X.; Wu, G.; Ruan, C.; Liu, X.; Ge, D. Nonenzymatic biosensor based on CuxO nanoparticles deposited on polypyrrole nanowires for improving detection range. Biosens. Bioelectron. 2013, 42, 141-147. [CrossRef]

166. Çiftçi, H.; Tamer, U. Functional gold nanorod particles on conducting polymer poly (3-octylthiophene) as non-enzymatic glucose sensor. React. Funct. Polym. 2012, 72, 127-132. [CrossRef]

167. Duan, X.; Liu, K.; Xu, Y.; Yuan, M.; Gao, T.; Wang, J. Nonenzymatic electrochemical glucose biosensor constructed by NiCo2O4@ Ppy nanowires on nickel foam substrate. Sens Actuators B Chem. 2019, 292, 121-128. [CrossRef]

168. Kailasa, S.; Geeta, B.; Jayarambabu, N.; Reddy, R.K.K.; Sharma, S.; Rao, K.V. Conductive polyaniline panosheets (CPANINS) for a non-enzymatic glucose sensor. Mater. Lett. 2019, 245, 118-121. [CrossRef]

169. Mohajeri, S.; Dolati, A.; Yazdanbakhsh, K. Synthesis and characterization of a novel non-enzymatic glucose biosensor based on polyaniline/zinc oxide/multi-walled carbon nanotube ternary nanocomposite. J. Electrochem. Sci. Eng. 2019, 9, 207-222. [CrossRef] 
170. The Nobel Prize in Chemistry 2000. Available online: https:/www.nobelprize.org/prizes/chemistry/2000/ summary/ (accessed on 27 August 2020).

171. Jia, X.; Ge, Y.; Shao, L.; Wang, C.; Wallace, G.G. Tunable conducting polymers: Toward sustainable and versatile batteries. ACS Sustain. Chem. Eng. 2019, 7, 14321-14340. [CrossRef]

172. Guo, X.; Facchetti, A. The journey of conducting polymers from discovery to application. Nat. Mater. 2020, 19, 922-928. [CrossRef]

173. Heyrovsky, J. The Nobel Prize in Chemistry 1959 Was Awarded to Jaroslav Heyrovsky for His Discovery and Development of the Polarographic Methods of Analysis. Available online: https:/www.nobelprize.org/ prizes/chemistry/1959/summary/ (accessed on 28 August 2020).

174. Marcus, R.A. The Nobel Prize in Chemistry 1992 Was Awarded to Rudolph A. Marcus for His Contributions to the Theory of Electron Transfer Reactions in Chemical Systems. Available online: https://www.nobelprize. org/prizes/chemistry/1992/summary/ (accessed on 28 August 2020).

175. Moorthy, M.; Kumar, V.B.; Porat, Z.E.; Gedanken, A. Novel polymerization of aniline and pyrrole by carbon dots. New J. Chem. 2018, 42, 535-540. [CrossRef]

176. Maruthapandi, M.; Saravanan, A.; Luong, J.H.T.; Gedanken, A. Antimicrobial properties of polyaniline and polypyrrole decorated with zinc-doped copper oxide microparticles. Polymers 2020, 12, 1286. [CrossRef]

177. Maruthapandi, M.; Saravanan, A.; Luong, J.H.T.; Gedanken, A. Antimicrobial properties of the polyaniline composites against Pseudomonas aeruginosa and Klebsiella pneumoniae. J Funct. Biomater. 2020, 11, 59. [CrossRef]

178. Cho, N.H.; Shaw, J.E.; Karuranga, S.; Huang, Y.; da Rocha Fernandes, J.D.; Ohlrogge, A.W.; Malanda, B.; Atlas, I.D. Global estimates of diabetes prevalence for 2017 and projections for 2045. Diabetes Res. Clin. Pract. 2018, 138, 271-281. [CrossRef]

179. Villena Gonzales, W.; Mobashsher, A.T.; Abbosh, A. The progress of glucose monitoring-A review of invasive to minimally and non-invasive techniques, devices and sensors. Sensors 2019, 19, 800. [CrossRef] [PubMed]

180. Jo, C.; Ahn, H.; Son, J.; Lee, J.; Byun, M. Packaging and irradiation effect on lipid oxidation, color, residual nitrite content, and nitrosamine formation in cooked pork sausage. Food Control 2003, 14, 7-12. [CrossRef]

181. Uzer, A.; Saglam, S.; Can, Z.; Ercag, E.; Apak, R. Electrochemical determination of food preservative nitrite with gold nanoparticles/p-aminothiophenol-modified gold electrode. Int. J. Mol. Sci. 2016, 17, 1253. [CrossRef] [PubMed]

182. Wrobel, A.G.; Benton, D.J.; Xu, P.; Roustan, C.; Martin, S.R.; Rosenthal, P.B.; Skehel, J.J.; Gamblin, S.J. SARS-CoV-2 and bat RaTG13 spike glycoprotein structures inform on virus evolution and furin-cleavage effects. Nat. Struct. Mol. Biol. 2020, 27, 763-767. [CrossRef] [PubMed]

183. Lee, J.; Kim, J.; Hyeon, T. Recent Progress in the synthesis of porous carbon materials. Adv. Mater. 2006, 18, 2073-2094. [CrossRef]

184. Song, Y.; Su, D.; Shen, Y.; Gong, C.; Song, Y.; Wang, L. Nitrogen-doped carbon foam as an efficient enzymatic biosensing platform for glucose sensing. Anal. Methods 2016, 8, 4547-4553. [CrossRef]

185. Chen, J.; Zhu, R.; Huang, J.; Zhang, M.; Liu, H.; Sun, M.; Wang, L.; Song, Y. A glucose biosensor based on glucose oxidase immobilized on three-dimensional porous carbon electrodes. Analyst 2015, 140, 5578-5584. [CrossRef] [PubMed]

186. Thakur, B.; Guo, X.; Chang, J.; Kron, M.; Chen, J. Porous carbon and Prussian blue composite: A highly sensitive electrochemical platform for glucose biosensing. Sens. Bio-Sens. Res. 2017, 14, 47-53. [CrossRef]

187. He, X.; Zhou, L.; Nesterenko, E.P.; Nesterenko, P.N.; Paull, B.; Omamogho, J.O.; Glennon, J.D.; Luong, J.H.T. Porous graphitized carbon monolith as an electrode material for probing direct bioelectrochemistry and selective detection of hydrogen peroxide. Anal. Chem. 2008, 4, 2351-2357. [CrossRef]

188. Cui, H.-F.; Du, L.; Guo, P.-B.; Zhu, B.; Luong, J.H.T. Controlled modification of carbon nanotubes and polyaniline on macroporous graphite felt for high-performance microbial fuel cell anode. J. Power Sources 2015, 283, 46-53. [CrossRef]

(C) 2020 by the authors. Licensee MDPI, Basel, Switzerland. This article is an open access article distributed under the terms and conditions of the Creative Commons Attribution (CC BY) license (http://creativecommons.org/licenses/by/4.0/). 